\title{
EL PRINCIPIO DE CAPACIDAD ECONÓMICA EN ESPAÑA: ¿VIGENCIA O SUPERACIÓN DE FACTO? SUPUESTOS PROBLEMÁTICOS EN LA IMPOSICIÓN DIRECTA ESTATAL Y EN EL GRAVAMEN MUNICIPAL SOBRE LAS PLUSVALÍAS
}

\author{
Antonio Vaquera García \\ avaqg@unileon.es \\ Profesor Titula r de Derec ho Fina nciero \\ Universidad de León
}

\begin{abstract}
Resumen
El presente trabajo plantea un análisis sobre el cumplimiento en la actualidad del mandato derivado del principio de capacidad económica establecido por la Constitución de 1978. Para llevar a cabo este objetivo se ha dividido el estudio en tres partes: en la primera se realiza un examen crítico de la definición y formulación del citado principio a través de la doctrina y la jurisprudencia del Tribunal Constitucional. En la segunda, se efectúa una comprobación general sobre una serie de figuras tributarias vigentes en España acerca de la efectiva incidencia que tiene dicha máxima en su

- Palabras clave: Capacidad económica; Principio constitucional; Tributo; Impuesto sobre la renta; Impuesto sobre sociedades; Impuesto sobre sucesiones y donaciones; Plusvalía articulación. Finalmente, en la tercera se detalla el último criterio aprobado por el Tribunal Constitucional a partir de la Sentencia relativa al Impuesto municipal sobre Incremento de Valor de los Terrenos de Naturaleza Urbana.
\end{abstract}

\begin{abstract}
This work presents an analysis of compliance currently the derivative mandate of the principle of economic capacity established by the Constitution of 1978. To accomplish this goal has divided the study in three parts: the first a brief test is performed critical of the definition and formulation of that principle by the doctrine and jurisprudence of the Constitutional Court. In the second, a general check on a number of existing tax figures in Spain about the actual impact having such a maximum in its articulation is made.
\end{abstract} - Keywords:

Taxpaying capacity; Constitutional principle; Tax; Income tax; Corporate tax; Inheritance tax; Appreciation; Capital gain Finally, in the third section, the last criterion approved by the Constitutional Court is outlined in the Judgment on the Municipal Tax on Increasing Value of Urban Land. 
I. Introducción - II. La formulación constitucional del principio y su modulación por el tribunal constitucional - III. Examen del respeto efectivo a la capacidad económica en diversos tributos estatales: A) Impuesto sobre la Renta de las Personas Físicas; B) Impuesto sobre Sociedades; C) Impuesto sobre Sucesiones y Donaciones - IV. Breve análisis de la Sentencia el Tribunal Constitucional de 11 de mayo de 2017 en relación con el gravamen de las plusvalías en el ámbito local - V. Reflexión final: ¿está superada dicha máxima constitucional? - Bibliografía

\section{INTRODUCCIÓN}

La presencia en la Constitución Española de 1978 de principios que inspiran y deben moldear la creación y aplicación de los tributos fue una novedad muy importante incluida por primera vez en una Carta Magna en nuestro país. Con ello se elevó al mayor rango interno normativo unas máximas que se pretende que sean el pilar fundamental de la tributación en relación tanto con los administrados como con los entes públicos.

En este sentido y, como es bien sabido, se incluyen diversos principios tanto de carácter material como formal y que no es preciso enumerar en este momento; en cambio, únicamente pretendemos llamar la atención del lector sobre uno en concreto que va a centrar el objeto de este trabajo: la capacidad económica del contribuyente del Estado español, como fórmula para medir su aptitud para ayudar a sufragar los gastos públicos de dicho Estado.

No es nuestro objetivo a lo largo de estas líneas volver a un tema -tan manido como interesante- como es el contenido y las obligaciones que se derivan de la correcta aplicación de la capacidad económica; estas circunstancias, a las que haremos una escueta mención en el segundo apartado de este trabajo, solo nos interesan a efectos de poder situar la atención ante el núcleo de nuestra exposición. Éste se centra en comprobar el adecuado respeto que las diversas disposiciones reguladoras de los tributos han tenido con dicha obligación constitucional y para ello hemos utilizado una metodología basada en verificar en la normativa de algunos tributos -no de todos pues ello daría lugar a una monografía exhaustiva y no a un artículo de una revista científica- y, dentro de ella, en algunos aspectos sustanciales que pensamos que debería cumplir con las requisitorias propias de dicha capacidad y que, a nuestro juicio, no se llevan a cabo acertadamente.

A todo ello se añade un análisis pormenorizado de la reciente Sentencia del Tribunal Constitucional acerca del gravamen sobre las plusvalías en el ámbito municipal, lo que nos permite constatar el estado de la cuestión actual en el seno del Alto Tribunal y nos ayuda a formular una serie de conclusiones relevantes al final del presente trabajo.

La explicación de la anterior aseveración debe ser algo más detallada; en efecto, el resto de principios constitucionales tributarios contenidos en el Alto Texto de 1978 no tendrían razón de ser sin la presencia de la capacidad económica. Así, los principios de justicia material del artículo 31 de la Constitución -igualdad, generalidad tributaria, 
progresividad y no confiscatoriedad - tienden siempre a ser definidos en relación con la riqueza de la que es titular o que gestiona un determinado individuo, lo que no es sino la demostración de su capacidad contributiva. Ello se comprueba fácilmente si ponemos en relación los mismos con ésta, del siguiente modo:

- En la igualdad tributaria por el hecho de tener que pagar lo mismo los que tengan la misma riqueza.

- En la generalidad en razón de que todos los que demuestren la misma riqueza deben contribuir a sufragar los gastos públicos sin que existan privilegios ni exenciones que no estén motivadas en otros principios constitucionales.

- En la progresividad de acuerdo a que debe contribuir más el que más capacidad económica tenga de forma más que proporcional al aumento de la misma, buscando de ese modo la redistribución de la renta.

- Finalmente, en la no confiscatoriedad debido a que no se puede hacer prescindir al sujeto de sus medios de vida, es decir, de sus rentas y bienes, por lo tanto, de su capacidad para hacer frente a las obligaciones cotidianas.

En consecuencia podemos colegir de lo anterior que si la riqueza del sujeto contribuyente no se tiene correctamente en cuenta a la hora de sufragar un tributo, éste quedará vacío de contenido o, al menos, no cumplirá con los mandatos derivados de la Constitución, lo que puede redundar en la declaración de inconstitucionalidad de su normativa reguladora $\mathrm{y}$, mucho más grave que ello, la injusticia de su aplicación práctica.

Evidentemente no es este el momento ni el lugar para entrar a juzgar la oportunidad ni las posibles mejoras de nuestro sistema tributario español, sino de poner de manifiesto algunos preceptos de nuestra normativa dedicada a los gravámenes públicos que pueden plantear la duda acerca de dicho cumplimiento constitucional y cuya utilización está dando lugar a que se sometan a imposición hechos imponibles que lesionen -o sean susceptibles de ello- la situación patrimonial de los administrados, hecho que no puede, ni debe, ser permitido por nuestro ordenamiento jurídico.

Para llevar a cabo nuestro cometido hemos optado por dividir el trabajo en dos bloques bien diferenciados: en primer lugar, se efectúa un rápido bosquejo del propio principio de capacidad económica, con el fin de que se sitúe bien el lector ante el punto de partida y la interpretación de dicha máxima que se pretende contrastar con la regulación legal de los tributos; en segundo término, se sitúa la parte más novedosa del estudio aplicando la definición y el contenido del citado principio a diversas figuras impositivas vigentes en el ámbito estatal y al impuesto municipal sobre plusvalías. En todos ellos no se trata de comprobar, en general, el contenido de la regla indicada a las categorías tributarias, tema ya objeto de estudio desde hace muchos años en un plano teórico, sino de analizar la normativa concreta de las mismas para ver si se pueden suscitar dudas sobre su utilización.

En definitiva vamos a contemplar la regulación de algunos tributos para dar respuesta al interrogante que nos planteamos en el título de este artículo: ¿está vigente el 
principio de capacidad económica en algunos tributos o se ha superado de facto por su empleo en la práctica? A ello dedicamos las siguientes páginas.

\section{LA FORMULACIÓN CONSTITUCIONAL DEL PRINCIPIO Y SU MODULACIÓN POR EL TRIBUNAL CONSTITUCIONAL}

El tenor literal del art. 31.1 de la Constitución Española de 1978 se limita a indicar que "Todos contribuirán al sostenimiento de los gastos públicos de acuerdo con su capacidad económica mediante un sistema tributario justo (...)", como no podía ser menos en un texto constitucional, puesto que no era el lugar apropiado para ofrecer detalles de sus preceptos; ello motivó el que se tuviera que completar el contenido y las exigencias de la capacidad económica a través de la doctrina tributaria y de la jurisprudencia constitucional.

En principio se puede colegir que se trata de un derecho-deber, como es bien sabido, ya que tanto limita a los poderes públicos para exigir los tributos solamente conforme a la riqueza del sujeto, como obliga a dicho administrado a contribuir de acuerdo con la misma, lo que denota el carácter de esta regla constitucional y su ubicación en la Sección $2^{a}$ del Capítulo II del Título I de la Constitución referida a los "Derechos y deberes de los ciudadanos".

1 Ya se ocupó del tema de la construcción dogmática del deber constitucional como deber jurídico el profesor RODRÍGUEZ BEREIJO, A. cuando indicaba que "Los deberes públicos, por contraposición a los derechos, son aquellas situaciones pasivas o de sujeción que se imponen a un sujeto para tutelar intereses que no son particulares suyos sino en beneficio de intereses generales de la comunidad.

En la doctrina alemana del Derecho público de la segunda mitad del siglo XIX (C.F. von GERBER) los deberes estatales que se enuncian en la Constitución se situaban en la esfera del sometimiento de los ciudadanos a la voluntad, al poder del Estado y no son más que aplicaciones o manifestaciones singulares de la relación general (orgánica) de sujeción de los ciudadanos al Estado como contrapartida de los derechos que la propia Constitución les atribuye como miembros de la colectividad estatal. Esta 'relación de poder' (Gewaltverhältnis) no significa y no debe entenderse -en la construcción de GERBERcomo una anulación o disolución del derecho, sino, antes al contrario, con una finalidad de garantía: la determinación de los límites jurídicos dentro de los cuales ha de desenvolverse y ejercerse el poder del Estado. La relación de poder que une al Estado y los ciudadanos en la que se contienen derechos (los derechos civiles y políticos) y deberes correlativos (deberes militares, deberes fiscales, etc.) que son la contrapartida al disfrute de los beneficios de la pertenencia del individuo a la comunidad y de la participación en la vida estatal.

Se extendió así en la dogmática del Derecho Público la construcción según la cual de la situación de supremacía en el que el Estado se encuentra y de la correlativa relación general de sumisión del individuo al Estado derivan los deberes públicos subjetivos. Deberes positivos (en el caso del deber de contribuir a los gastos públicos), que obligan a los particulares a realizar actos y prestaciones a favor del Estado que coadyuven al cumplimiento de sus fines".

(Vid.: "El deber de contribuir como deber constitucional. Su significado jurídico", Revista Española de Derecho Financiero, núm. 125, 2005, págs. 19 y 20). 
Por lo tanto, la configuración del deber de contribuir se ha diseñado como una manifestación del principio de solidaridad que subyace en los valores fundamentales del ordenamiento constitucional, deber cuya realización resulta especialmente apremiante y que justifica la derivación de exigencias, incluso a otros titulares no directamente relacionados, es decir, un genérico deber de colaboración con la Administración ${ }^{2}$.

Así, como indica el profesor RODRÍGUEZ BEREIJO, el deber de contribuir proclamado en la Constitución aunque se dirige al individuo como tal, se configuraría, en su estructura normativa como un mandato dirigido al legislador para que concrete dicho deber y lo dote de sanción y no como vinculación de la conducta de las personas. Son los poderes públicos quienes se encuentran vinculados a él y a la creación respecto de los particulares de las obligaciones correspondientes, precisamente, en las condiciones y dentro de los límites que establece la Constitución ${ }^{3}$.

Con todo y con eso, la doctrina tributaria ha tratado de dar contenido al principio que nos ocupa y cuyo detalle no es posible abordar en esta sede, sino únicamente destacar algunas aportaciones que nos parecen de interés; en este sentido, se ha afirmado que el origen económico que se le reconoce a esta máxima hizo que se dudara de su

2 Según opina ESCRIBANO LÓPEZ, F.: La configuración jurídica del deber de contribuir. Perfiles constitucionales, Civitas, Madrid, 1988, pág. 327 y ss.

3 Vid.: "El deber de contribuir como deber constitucional. Su significado jurídico", ob. cit., pág. 24. Más adelante (pág. 25) el citado profesor escribe: "Fruto acaso del defectuoso entendimiento del significado jurídico de los deberes constitucionales es la utilización equivoca del concepto de 'deber constitucional de contribuir' como equivalente y aun sustitutivo del de obligación tributaria como situación jurídica pasiva que surge de la relación jurídica tributaria, que comienza a encontrarse también en trabajos doctrinales recientes de nuestro Derecho Tributario, donde deber de contribuir y sujeto del deber de contribuir se identifican y sustituyen con los que, tradicionalmente, la dogmática jurídicotributaria ha acuñado como (...) como si de una misma situación jurídica se tratara".

Finalmente, el mismo autor señala una triple función jurídico-política de la formulación constitucional del deber de contribuir: "a) de legitimación del tributo, cuyo fundamento o justificación descansa no ya en la simple fuerza o poder de supremacía del Estado (frente a la impotencia del súbdito), sino en el deber de solidaridad de los ciudadanos de contribuir al sostenimiento de los gastos públicos por su interés, en tanto miembros de la comunidad política, en la existencia y mantenimiento del Estado (...);

b) de límite y de garantía jurídica, en cuanto la norma constitucional fija los límites del deber de contribuir, sin que el Estado pueda constreñir al particular a pagar más allá de tales límites o en razón o medida de criterios o cánones distintos de los fijados constitucionalmente (la capacidad económica). Y al propio tiempo, de garantía a los ciudadanos, pues aunque las normas constitucionales que imponen deberes cívicos más que garantizar la libertar y la propiedad individual las constriñen (...), sin embargo es también una norma de garantía en cuanto indirectamente limita el derecho de supremacía del Estado, que ha de configurar en cada caso, como elemento base de la imposición supuestos de hecho que sean reveladores de capacidad económica;

c) de orientación programática de la actuación de los poderes públicos, primordialmente del legislativo, al cual se le encomienda la creación de un sistema tributario justo como cauce para la actuación del deber de contribuir proclamado constitucionalmente, y funcionalmente conexo, como hemos dicho, con el gasto público". (Ob. cit., págs. 32 y 33 ). 
viabilidad como principio jurídico, hecho que se ha superado claramente en la actualidad $^{4}$.

Otro hecho debatido es la construcción conceptual en torno a la expresión "capacidad económica" en lugar de la de "capacidad contributiva" como establece el art. 53 de la Constitución Italiana de 1947. Para ello ambos términos se han utilizado para identificar el mismo principio, aunque se ha anotado 5 que la capacidad contributiva engloba en su seno la referencia a una serie de elementos éticos, sociológicos, políticos y económicos. Por el contrario la expresión capacidad económica se refiere tan sólo a la titularidad de un cierto grado de riqueza manifestada a través del gasto, del patrimonio o de la renta. En definitiva, se ha tratado en la Constitución Española de acotar más el término y aunar la riqueza de origen económico con la noción jurídica de capacidad para contribuir al sostenimiento de los gastos públicos ${ }^{6}$.

En definitiva y centrándonos en el tema que desarrollamos en el presente trabajo, hay que poner en relación la capacidad económica del hipotético contribuyente con las diferentes figuras tributarias, lo que nos orientará a efectos de realizar el balance acerca del respeto de las mismas con dicha máxima.

Así, por lo que respecta a los tributos directos, hay que acudir a las palabras del profesor SÁINZ DE BUJANDA, cuando escribía: "La renta neta y actual, efectivamente percibida por cada individuo, no es, sin embargo, integramente computable para fijar la extensión de la riqueza imponible del sujeto. Los gastos vitales mínimos han de ser detraídos de esa renta. Sólo la diferencia puede considerarse disponible para el pago del tributo, y, por tanto, sólo de ella podrá afirmarse que confiere capacidad contributiva al perceptor" $"$.

En cuanto a los de carácter indirecto, el citado profesor distinguía entre impuestos sobre el tráfico patrimonial e imposición sobre el consumo. Respecto a los primeros indicaba que la doctrina no es unánime, aunque afirmaba que, en términos generales, el pronunciamiento sobre su respeto a la capacidad económica era favorable, ya que es cierta riqueza que circula y que, por ende, supone un volumen de imposición que

4 Vid. AIZEGA ZUBILLAGA, J.M.: La utilización extrafiscal de los tributos y los principios de justicia tributaria, Universidad del País Vasco, Bilbao, 2001, pág. 122.

5 Vid. CORTÉS DOMÍNGUEZ, M.: "Los principios generales tributarios", XVI Semana de Estudios Financieros, Edersa, Madrid, 1968, págs. 99 y ss.

6 Como indica ALBIÑANA GARCÍA-QUINTANA, la expresión 'capacidad económica' sustituyó a la de 'capacidad contributiva' en el Texto Constitucional tras una modificación operada en su tramitación parlamentaria, cuya justificación es similar a la indicada en el texto. (Vid.: "Artículo 31. El gasto público", Comentarios a las Leyes Políticas, dirección ALZAGA, O., tomo III, Edersa, Madrid, 1983, pág. 306.

Para la doctrina italiana, puede consultarse el resumen que realiza FALSITTA, G. (Manuale di Diritto Tributario. Parte Generale, $2^{\text {a }}$ ed., Cedam, Padua, 1997, págs. 139 y ss.). En él se abarcan todas las posibles acepciones de la "capacità contributiva", considerándose como presupuesto para contribuir, como parámetro, como límite máximo de gravamen y como función solidaria y garantía del sistema tributario.

7 Vid.: Hacienda y Derecho. Estudios de Derecho Financiero, volumen III, Instituto de Estudios Políticos, Madrid, 1963, pág. 206. 
recae sobre elementos reales que provocan y que permiten disponer de medios de pago, como el tributo sobre las adquisiciones mortis causa. En cuanto a los tributos relativos al consumo le asaltaban más dudas, al decir que es intensa la tensión entre los ideales fiscales y la realidad tributaria, por el carácter ciertamente regresivo de estos gravámenes.

Finalmente es importante señalar que para adaptar la carga tributaria que cada sujeto ha de soportar a su capacidad individual de pago no es suficiente conocer las fuentes o manifestaciones de su riqueza ni medir ésta con el empleo de los criterios estimativos ya esbozados. Es necesario, además, utilizar ciertos métodos impositivos que conduzcan a una determinación precisa de los pagos tributarios que cada individuo ha de realizar. En términos amplios, contemplado el problema dentro de la órbita de la distribución tributaria, puede atribuirse la consideración de métodos impositivos al conjunto de medidas técnicas sancionadas por la normativa tributaria que, partiendo de una manifestación de la riqueza imponible de un sujeto, conducen a la determinación de la cuota impositiva que por esa riqueza ha de satisfacer. Métodos impositivos son, por tanto, en esta amplia acepción, no sólo las distintas modalidades de los tipos de gravamen -fijos, proporcionales o progresivos, en sus variadas especies-, sino también la estructura -real o personal- de los presupuestos de hechos de las obligaciones tributarias y el criterio -objetivo o subjetivo- que pueda utilizarse para la determinación de las cuotas. Esos distintos elementos son susceptibles de muy variadas combinaciones.

Pasando ya a la formulación que el Tribunal Constitucional ha ido realizando de la máxima que nos ocupa, podemos adelantar que las conclusiones a las que ha llegado el Alto Tribunal no son en modo alguno diáfanas, en nuestra opinión, ya que el cuerpo de doctrina jurisprudencial elude entrar en mayores consideraciones que las ya sabidas de buscar la riqueza allá donde ella se encuentre; en señalar como índices de dicha riqueza la adquisición o gasto de un renta, la posesión de un patrimonio y la circulación de bienes; en indicar q no hay capacidad económica si solo se quiere gravar una renta ficticia o inexistente $\mathrm{y}$, finalmente, en salvar el respeto a dicho principio si únicamente concurre una renta potencial ${ }^{8}$.

Como ha señalado algún autor ${ }^{9}$, nuestra jurisprudencia ha conectado la interpretación de los principios del art. 31 con los valores positivizados en el artículo 1.1 de la Carta

8 Ahorramos al lector la enojosa enumeración de las Sentencias del Tribunal Constitucional sobre el tema y que se pueden consultar en diferentes trabajos: NIETO MONTERO, J.J.: "El principio de capacidad contributiva y su reflejo en la jurisprudencia constitucional", Revista de Derecho Financiero y de Hacienda Pública, núm. 238, 1995, págs. 917 y ss.; VARONA ALABERN, J.E.: "Concepto de tributo y principio de capacidad económica", Revista Española de Derecho Financiero, núm. 135, 2007, págs. 541 y ss.; APARICIO PÉREZ, A.: "La falacia de la capacidad económica como criterio informador de los tributos”, Información Fiscal, núm. 79, 2007, págs. 13 y ss.; FERNÁNDEZ JUNQUERA, M. y GARCÍA-OVIES SARANDESES, I.: "Una visión sobre la financiación autonómica", Nueva Fiscalidad, núm. 4, 2016, págs. 9 y ss. y ROMERO ABOLAFIO, J.J.: "Proyección de los valores superiores sobre la fiscalidad y el gasto público", Nueva Fiscalidad, núm. 3, 2016, págs. 45 y ss.

9 ROMERO ABOLAFIO, J.J.: ob. cit., pág. 81. 
Magna, invocados a través de la fórmula del "Estado social y democrático de Derecho" en nuestra jurisprudencia. De este modo, "En relación a la vertiente de los ingresos, sin ánimo de exhaustividad, podemos encontrar esta conexión explicitada en el ATC 71/2008: “(...) sólo cabe exigir que la carga tributaria de cada contribuyente varie en función de la intensidad en la realización del hecho imponible en aquellos tributos que por su naturaleza y caracteres resulten determinantes en la concreción del deber de contribuir al sostenimiento de los gastos públicos que establece el art. 31.1 CE. Éste es, como hemos tenido ocasión de afirmar varias veces, el caso del impuesto sobre la renta de las personas físicas, que 'por su carácter general y personal, y figura central de la imposición directa, constituye una de las piezas básicas de nuestro sistema tributario. Se trata, indudablemente-hemos señalado-, de un tributo en el que el principio de capacidad económica y su correlato, el de igualdad y progresividad tributarias, encuentran una más cabal proyección, de manera que es, tal vez, el instrumento más idóneo para alcanzar los objetivos de redistribución de la renta (art. 131.1 CE) y de solidaridad (art. 138.1 CE) que la Constitución española propugna (...) y que dotan de contenido al Estado social y democrático de Derecho (art. 1.1 CE)' (STC 182/1997, de 28 de octubre, F. 9; en el mismo sentido, SSTC 134/1996, de 22 de julio, F. 6; 46/2000, de 17 de febrero, F. 6; 137/2003, de 3 de julio, F. 7; 108/2004, de 30 de junio, F. 8 y 189/2005, de 7 de julio, F. 8)"'"10.

Además, la capacidad económica debemos entenderla no solo como un principio rector del sistema tributario que informa la definición y estructura de los hechos imponibles y bases tributarias de los gravámenes, sino también como un límite al legislador en los diversos sentidos que se han formulado en la doctrina y que consisten en un límite cualitativo y uno cuantitativo; el primero, en relación a los llamados tributos con fines no fiscales y sobre los que ya nos hemos ocupado de manera extensa en publicaciones anteriores ${ }^{11}$; el segundo, como medida del impuesto, es decir, como prohibición de confiscatoriedad ${ }^{12}$. En consecuencia podemos suscribir las palabras del profesor NIETO MONTERO, J.J. cuando finaliza su trabajo opinando que "se contribuye porque se manifiesta riqueza, pero para que tal contribución sea justa, la capacidad ha de actuar como límite, precisamente ayudada de la igualdad y su manifestación tributaria, la progresividad, dentro de los límites de la no confiscatoriedad"13.

$10 \quad$ Ibidem, pág. 82.

11 Vid.: "La tributación con fines ecológicos: El reciente gravamen francés para la protección del ambiente atmosférico", Revista de Información Fiscal, núm. 14, 1996, págs. 7-19; Fiscalidad y Medio Ambiente, Lex Nova, Valladolid, 1999; "Propuestas comunitarias sobre la fiscalidad de la energía", Noticias de la Unión Europea, núm. 193, 2000, págs. 89-98.; "La fiscalidad ambiental: algunas reflexiones actuales", Nueva Fiscalidad, núm. 3, 2006, págs. 9-38; "La tributación medioambiental en las Comunidades Autónomas y en el Derecho Comparado", Economía y medio ambiente, núm. 113, 2007, págs. 50-67; "La protección ambiental como alternativa de financiación de las Comunidades Autónomas, el caso de los impuestos sobre usos y aprovechamientos del agua embalsada de Galicia y Castilla y León", Thomson Reuters-Lex Nova, Valladolid, 2013, 127-170.

12 En palabras de NIETO MONTERO, J.J.: ob. cit., págs. 936 y ss.

13 Ibidem, pág. 961. 
El mismo autor vuelve a reflexionar sobre el tema en un trabajo más reciente a la luz de las medidas tributarias aprobadas durante los últimos años y que se han motivado en la crisis económica que está asolando nuestro país; en efecto, las conclusiones a las que llega, que compartimos plenamente, consisten en considerar que la crisis económica ha sido utilizada por los poderes públicos para subvertir el orden constitucional en materia tributaria, de modo que ni se respeta la distribución de competencias derivadas de la Carta Magna, ni se legisla con respeto a los principios de justicia, que han dejado de operar como límites al poder tributario y como guías de la acción normativa. Ello podría llevar, como han señalado algunos autores, a considerar la acción legislativa como una acción corrupta, cuya única solución pasa por la atribución a los órganos jurisdiccionales ordinarios de la potestad de aplicación directa de la norma constitucional y la consecuente inaplicación de las normas inferiores que la contravengan ${ }^{14}$.

De lo que no cabe ninguna duda de es de la plena aplicación del tantas veces citado principio de capacidad económica en el ámbito de la figura tributaria por excelencia que es el impuesto; por otra parte, en lo que se refiere a la contribución especial, por su propia naturaleza creemos que cumple con las exigencias del mismo, ya que el presunto beneficio o aumento de valor de los bienes del contribuyente denotan ya la mayor riqueza del mismo para poder sufragar el gravamen ${ }^{15}$.

14 Vid.: NIETO MONTERO, J.J.: "El artículo 31 de la Constitución Española: ¿otra víctima de la crisis económica?", Dereito, vol. 22, noviembre, 2013, págs. 394 y 395.

15 Comentando un Auto del Tribunal Constitucional 71/2008, de 26 de febrero, por el que se inadmitió una cuestión de constitucional en relación al principio que nos ocupa, el profesor RODRÍGUEZ BEREIJO escribe: "La posición del Tribunal respecto del principio de capacidad económica puede resumirse diciendo que si bien no puede gravarse con un impuesto una capacidad económica inexistente (virtual o ficticia) -aunque sí la que equivale a renta potencial-no se exige, en cambio, que el gravamen del impuesto esté en función de la concreta capacidad económica. De este modo, una parte de los impuestos que integran el sistema tributario quedarán fuera del ámbito tutelado por la norma constitucional y fuera del contenido declarado de la capacidad económica como exigencia constitucional del justo reparto de la contribución de todos al sostenimiento de los gastos públicos. Respecto de ellos, la capacidad económica no puede actuar como parámetro o medida de cuantificación de la imposición sino, a lo sumo, como límite último y extremo que impide un resultado confiscatorio.

Estamos -en mi opinión-ante una reducción dificilmente admisible del ámbito declarado de una norma constitucional, en este caso el principio de capacidad económica (art. 31.1 $C E)$, al que se vacía de contenido. Según la doctrina vertida en este Auto, el Tribunal Constitucional parece entender el principio de capacidad económica como una norma que opera frente al legislador como criterio y límite dirigido únicamente a preservar la justicia, racionalidad y coherencia del sistema tributario en su conjunto y por tanto, sólo aplicable a aquellas figuras impositivas que ocupan una posición troncal dentro de la estructura del sistema fiscal, y no a fijar la medida de la contribución de cada uno al sostenimiento de los gastos públicos. Así, se despoja al precepto constitucional de su vertiente subjetiva y garantista (facultad reaccional) respecto de la tributación de cada contribuyente frente a toda figura impositiva, como concreta medida de la igualdad en la determinación de la carga tributaria que debe soportar; cuya modulación de acuerdo con su capacidad económica (en función de la intensidad en la realización del hecho imponible) sólo sería predicable, según dicha doctrina, en aquellos tributos «que por su naturaleza y caracteres 
En cambio, pasando al campo de la tasa, la cuestión es más discutible, pues hallar resquicios de riqueza gravable es más complicado en ciertas situaciones y, más todavía, intentar aunar o adaptar la cuota tributaria de la misma a las circunstancias del contribuyente, hecho que ha llevado a la doctrina a preguntarse sobre si dicho principio es inherente a la figura de la tasa, como realiza el profesor VARONA ALABERN, quien opina que se trata de una compleja y sutil cuestión que la doctrina tributaria viene debatiendo desde hace muchos años, sin que se haya logrado alcanzar una conclusión unánime. La mayor parte de los tributaristas españoles han defendido la necesaria presencia de capacidad económica en la tasa. Otros autores son, por una parte, conscientes de los problemas que plantea el admitir la inherencia de este principio en esta clase de tributos, llegado incluso a afirmar que la tasa 'no deviene como consecuencia de una manifestación de capacidad económica', pero cuando se ven abocados a extraer conclusiones, ya por el art. 31.1 de la Constitución, ya por el peso de nuestra tradición doctrinal, no acaban de dar el paso y terminan por concederle cierta relevancia. Tampoco faltan quienes consideran que tal principio opera en sentido negativo, ya que a la tasa no se le pide que consiga la progresividad del sistema, lo que sería técnicamente imposible, sino al menos que no lo desvirtúe ${ }^{16}$.

Por nuestra parte nos adherimos al autorizado parecer en materia de tasas como es la de la profesora RUIZ GARIJO para quien es cierto que si afirmamos tajantemente el carácter de contraprestación (existencia de bilateralidad), nos encontramos con que no es posible graduar la cuantía de la tasa en función del principio analizado. La propia Ley de Tasas y Precios Públicos y la Ley Reguladora de las Haciendas Locales han establecido que 'en la fijación de las tasas se tendrá en cuenta, cuando lo permitan las características del tributo, la capacidad económica de las personas que deben satisfacerla'. En la segunda, se declara que 'para la determinación de la cuantía de las tasas deberán tenerse en cuenta criterios genéricos de capacidad económica de los sujetos obligados a satisfacerlas'. Sin embargo, hay que tener en cuenta lo establecido en el art. 31.1 de la Constitución: que 'todos contribuirán al sostenimiento de los gastos públicos de acuerdo con su capacidad económica'. En este sentido, la capacidad económica de los sujetos llamados a contribuir es un criterio que debe ser tenido en

resulten determinantes en la concreción del deber de contribuir», como serían los grandes impuestos generales sobre la renta, el patrimonio y el gasto o consumo.

Doctrina que, como se sostiene acertadamente en el Voto Particular discrepante del MagistradoManuel Aragón Reyes, contradice el texto de la Constitución ("todos contribuirán... de acuerdo con su capacidad económica») y la propia jurisprudencia del Tribunal; de manera singular, la STC 193/2004, F. J. 5', a propósito de una norma del Impuesto sobre Actividades Económicas, en la cual explícitamente se rechazó la argumentación del Abogado del Estado en el sentido de que el principio de capacidad económica resulta predicable únicamente del sistema tributario en su conjunto, con la cual pretendia justificar la existencia de figuras impositivas, directas de carácter real, sobre el mero ejercicio de actividades empresariales y que se exijan por una capacidad económica meramente virtual o ficticia dado que no ocupan una posición central en el sistema tributario". (Cfr.: RODRÍGUEZ BEREIJO, A.: "Una vuelta de tuerca al principio de capacidad económica”, Revista Española de Derecho Financiero, núm. 142, 2009, págs. 11 y 12$)$.

16 Vid.: VARONA ALABERN, J.E.: "Concepto de tributo y de principio de capacidad económica”, Revista Española de Derecho Financiero, núm. 135, 2007, págs. 576 y 577. 
cuenta en cada uno de los tributos. Claro está que principio tendrá distinto protagonismo según nos encontremos con tributos de naturaleza impositiva o de naturaleza retributiva (tasas). Mientras que en los primeros dicho principio es su causa y fundamento principal (es un criterio de contribución), en el resto de tributos con estructura retributiva, la capacidad económica opera como un límite a la contribución de las tasas. Esta capacidad económica obliga a considerar el mínimo vital del sujeto beneficiado (mediante el establecimiento de exenciones). En definitiva, permitir la utilización gratuita de un servicio público se inscribe en este mínimo de subsistencia que debe ser respetado por el tributo.

Más discutible es considerar la capacidad económica del sujeto pasivo como un criterio de graduación de la cuantía de la tasa. Por un lado, y por lo que se refiere a la prestación de un servicio público, como el de recogida de basuras, tanto la Ley de Tasas y Precios Públicos como la Ley Reguladora de las Haciendas Locales disponen que 'la cuota tributaria podrá consistir en una cantidad fija señalada al efecto, determinarse en función de un tipo de gravamen aplicable sobre elementos cuantitativos que sirvan de base imponible o establecerse conjuntamente por ambos procedimientos' (art. 19.4 Ley de Tasas y art. 24.3 Ley Reguladora). A partir de este precepto, ningún reproche merece, en principio, la cuantificación de la tasa por recogida de basuras atendiendo al número de estrellas o a las plazas disponibles de los hoteles (asignándosele una cuantía fija, estableciéndose como base imponible a la que aplicar un tipo de gravamen o utilizándose ambos criterios).

Por otro lado, sin embargo, hay que tener en cuenta dos límites establecidos por las Leyes citadas (y que, en nuestra opinión, contribuyen a salvar la indeterminación del precepto anterior). El primero, el establecido en el art. 19.2 de la Ley de Tasas y Precios Públicos y en el art. 24.2 de la Ley Reguladora de las Haciendas Locals: 'el coste real o previsible del servicio o actividad de que se trate o, en su defecto, del valor de la prestación recibida'. Como puede observarse, y aquí surge otro de los problemas en la cuantificación de las tasas, ambos preceptos se refieren al 'coste conjunto'. Es decir, según dicho precepto, la cuantía total recaudada no deberá exceder del coste total del servicio, tal y como se afirma en la sentencia comentada. ¿Debe, de este modo, prescindirse del coste individual provocado o del que se beneficia el sujeto pasivo y, por ello, desvirtuarse este importante límite? En nuestra opinión no. Ello por diversos motivos. El primero, porque en ambos preceptos, como acabamos de ver, se establece un criterio de aplicación subsidiaria: 'el valor de la prestación recibida'. Es decir, si el coste global del servicio no puede ser determinado, debe atenderse al valor de la prestación recibida por el beneficiario del servicio público o de la actividad administrativa.

En segundo lugar, un segundo límite en la cuantificación de las tasas es el principio de equivalencia, establecido en el art. 7 de la Ley de Tasas y Precios Públicos (de aplicación supletoria a las Haciendas Locales, tal y como dispone la Disposición adicional séptima de dicha Ley): 'las tasas tenderán a cubrir el coste del servicio o de la actividad que constituya su hecho imponible' (art. 7). Si el hecho imponible es la prestación de un servicio o la realización de una actividad administrativa en beneficio 
de un sujeto determinado, a partir de este precepto, el límite del importe total del servicio deberá aplicarse con carácter individual ${ }^{17}$.

Para finalizar este epígrafe no nos resta sino hacernos eco de dos opiniones que muestran aspectos actuales de la problemática en la aplicación práctica del principio de capacidad económica y que nos sirven para enlazar en el apartado siguiente con el breve recorrido que queremos efectuar a través de algunos tributos; en primer lugar, la del profesor APARICIO PÉREZ cuando sienta como conclusiones a este tema, entre otras, que la capacidad económica no puede predicarse de todos los tributos sino sólo y exclusivamente de los impuestos, por lo tanto no puede aplicarse a la totalidad del sistema extendiéndola a las tasas y a las contribuciones especiales, ya que estos gravámenes por la propia naturaleza que les ha dado el legislador se basan en el principio del beneficio y no de la capacidad de pago. También considera que responde siempre a una realidad económica real y directa. Nada más contrario de ella que gravar una riqueza o renta potencial o virtual, siendo en el derecho español una referencia genérica sin contenido propio, debiendo aplicarse, en consecuencia, a través de otros principios como el de generalidad o de no confiscatoriedad ${ }^{18}$.

En segundo término las profesoras FERNÁNDEZ JUNQUERA y GARCÍA-OVIES SARANDESES, cuando, al referirse a los problemas de los tributos con fines no fiscales piensan que la situación creada podría conducir a entender que es la finalidad extrafiscal, pretendidamente justificada en la mayoría de los tributos autonómicos, la que los identifica y distingue de los estatales. Pero más bien creemos que se trata, en muchos casos, de una justificación falaz y que, si en su momento se destinó un gran esfuerzo a la justificación constitucional de los tributos con fines extrafiscales, ahora toca reconocer que dicha extrafiscalidad esconde, en la mayor parte de las veces, una pretensión claramente recaudatoria. Es más, nos atreveríamos a decir que estamos en un punto de inflexión y que si, hace un tiempo, se hablaba de la 'crisis' del principio de capacidad económica, ahora deberíamos tender de nuevo al 'apogeo' de dicho principio si no queremos caer definitivamente en su abandono. A nuestro juicio, la invocación de la finalidad extrafiscal para justificar el establecimiento de muchos tributos autonómicos, de un lado, $\mathrm{y}$, de otro, para introducir en nuestro sistema tributario un conjunto poco conexo de beneficios fiscales, con fines políticos en muchos casos, distorsiona sustancialmente dicho 'sistema' y contribuye a que la capacidad económica se vaya diluyendo como principio inspirador del mismo ${ }^{19}$.

En fin, esperemos que la realidad económica que domina la actuación tributaria en nuestro país no acabe por domeñar y someter al principio de la capacidad contributiva cuyo respeto dudamos que se realice correctamente en algunas figuras impositivas, como tendremos ocasión de comprobar en el siguiente epígrafe de este trabajo. Para

17 Vid.: RUIZ GARIJO, M.: “¿Principio de capacidad económica en la cuantificación de la tasa por recogida de basuras? Una llamada sobre el carácter impositivo de algunas tasas", Jurisprudencia Tributaria, núm. 155, 2003, págs. 2 y 3.

18 Vid.: APARICIO PÉREZ, A.: "La falacia de la capacidad económica como criterio informador de los tributos”, Información Fiscal, núm. 79, 2007, pág. 44.

19 Vid.: FERNÁNDEZ JUNQUERA, M. y GARCÍA-OVIES SARANDESES, I: ob. cit., pág. 30 . 
dicha verificación utilizaremos el método de contrastar algunos aspectos de diversos gravámenes en una doble perspectiva: en primer lugar, considerando si existe una auténtica riqueza que deba estar obligada a contribuir y, en segundo término, si se ha tenido en cuenta la tantas veces citada capacidad económica para modular la cuota a pagar por parte de los sujetos pasivos, circunstancia esta última que parece soslayar el Tribunal Constitucional, como hemos comprobado anteriormente.

\section{EXAMEN DEL RESPETO EFECTIVO A LA CAPACIDAD ECONÓMICA EN DIVERSOS TRIBUTOS ESTATALES}

\section{A) Impuesto sobre la Renta de las Personas Físicas}

Comenzamos el repaso a algunos tributos actualmente exigidos en España con carácter estatal -dejando al margen el hecho de que una parte de los mismos están, como es bien sabido, cedidos en su recaudación total o parcialmente a las Comunidades Autónomas-, con el análisis del impuesto más representativo del sistema tributario, es decir, con el Impuesto sobre la Renta de las Personas Físicas.

Este gravamen supone la pieza central de dicho sistema pues da la nota de progresividad al mismo y trata de adecuar "la renta de las personas físicas de acuerdo con su naturaleza y sus circunstancias personales y familiares", tal como reza el art. 1 de su Ley reguladora.

Todo ello nos llevaría a pensar que este tributo es el más respetuoso con el principio de capacidad económica que es objeto de este estudio, pues tanto la propia riqueza sometida a gravamen -la renta de una persona física residente en España-, como los medios de estimación de la base imponible y de cálculo de la cuota parecen responder y estar condicionados a la efectiva presencia de dicha renta.

Sin embargo en un análisis detenido de algunos preceptos de la Ley reguladora del Impuesto (Ley 35/2006, de 28 de noviembre) descubrimos problemas de respeto a la máxima constitucional, que pasamos a describir someramente.

En primer lugar, el art. 7.m), que declara exentas "las ayudas de contenido económico a los deportistas de alto nivel ajustadas a los programas de preparación establecidos por el Consejo Superior de Deportes con las federaciones deportivas españolas o con el Comité Olímpico Español (...)".

Si contrastamos esta exención con la presencia -0 , en este caso, ausencia- de riqueza se comprueba que la razón de ser de esta medida tributaria no está incidiendo en una falta de capacidad económica o en un nivel menor de capacidad que otro tipo de contribuyentes; en efecto, si se trata de ayudar a deportistas para realizar programas específicos de preparación, entendemos que debería abrirse el abanico de ayudas a todo tipo de deportistas, no solo a los de alto nivel, lo que discrimina a los que no tengan dicha conceptuación, a la par de que los que no tengan dicha adjetivación 
normalmente tendrán un menor acceso a las vías de financiación, al igual que a otro tipo de ingresos como de tipo publicitario o de derechos de imagen.

Además, a la hora de someter a gravamen a los deportistas que no tengan ese alto nivel o que no estén incluidos en los programas de preparación específicos, no se modula la cuota a pagar por el impuesto de ninguna forma, con lo que se ven beneficiados los que encima reciben un ingreso extra, frente a los que no obtienen ninguna para ayudarles en sus actividades ${ }^{20}$.

La conclusión por lo tanto es dudar del respeto al principio de capacidad económica, hecho que comprobaremos en el resto de artículos de la Ley del Impuesto sobre la Renta de las Personas Físicas que seguimos comentando.

En segundo término, el art. 17.1.b) considera como rendimientos del trabajo las "prestaciones por desempleo". En este caso, no vamos a entrar en la polémica sobre si es un subsidio o una renta real, ya que se supone que su obtención viene motivada por la necesidad de conseguir un mínimo vital de subsistencia en tanto se está buscando un empleo por parte de la persona beneficiada por la misma. Ya anteriormente se había declarado la exención de este tipo de ingresos en el artículo 9.1 de la Ley 18/1991, de 6 de junio, del Impuesto, cambiándose el parecer del legislador por medio del artículo 62 de la Ley 21/1993, de 29 de diciembre, de Presupuestos Generales del Estado para el año 1994. Desde entonces se ha hecho tributar al subsidio por desempleo salvo en los casos de pago único con algunos requisitos, tema que excede el contenido de este trabajo.

Pensamos que no existe una riqueza en sí susceptible de gravamen, máxime cuando el perceptor de la ayuda por desempleo no obtiene otros ingresos o cuando sí están exentas, por ejemplo, las prestaciones de la Seguridad Social por gran invalidez o incapacidad permanente absoluta (art. 7.f) de la Ley del Impuesto). Además, podría modularse la cuota a pagar, pues no son un rendimiento del trabajo ordinario como pueden ser los demás, al menos en las pensiones por desempleo que sean de cuantías más bajas, y no solo dejar todo el peso de la adaptación de las circunstancias personales del contribuyente al modo de proceder del mínimo personal y familiar.

Otro aspecto es el contenido en el art. 17.2.a).7 $7^{\mathrm{a}}$, cuando establece el gravamen de "las prestaciones percibidas por los beneficiarios de los seguros de dependencia conforme a lo dispuesto en la Ley de Promoción de la Autonomía Personal y Atención a las Personas en Situación de Dependencia". Podemos realizar un razonamiento parecido al anterior, en función de la menor - o incluso, nula- riqueza de la que dispone el contribuyente que acude a dichas figuras de seguro, pues necesitará de unas ayudas para poder subvenir a sus necesidades básicas que en otros contribuyentes no sean

20 Vid.: CORCUERA TORRES, A.: "La exención de deportistas de alto nivel en la nueva Ley del Impuesto sobre la Rentas de las Personas Físicas", Revista Jurídica de Deporte y Entretenimiento, núm. 2, 1999, págs. 13 y ss. y GARCÍA NOVOA, C.: "Exenciones en el IRPF de las ayudas a deportistas de alto nivel y de las indemnizaciones por despido percibidas por técnicos y jugadores", en la Obra Colectiva: Régimen Tributario del Deporte, Thomson-Reuters, Navarra, 2013, págs. 29 y ss. 
necesarias al disponer de mayor capacidad económica ${ }^{21}$. En este sentido creemos que gran parte de las mismas deberían ser declaradas exentas.

Muy similar al anterior es el caso del art. 17.2.f), que considera rendimientos del trabajo "las pensiones compensatorias recibidas del cónyuge y las anualidades por alimentos, sin perjuicio de lo dispuesto en el artículo 7 de esta Ley".

La diferencia de trato entre pensión compensatoria debida al cónyuge -aunque pensamos que debería la norma hablar más bien del excónyuge- y los alimentos recibidos por los hijos es clara, pues los últimos se declaran exentos y la primera sujeta. Las razones del legislador se dirigen a la protección de los menores y al hecho de que el antiguo integrante del matrimonio es una persona mayor de edad que puede obtener otra fuente de ingresos; sin embargo, nuestra opinión va un poco más allá y creemos que habría que haber arbitrado alguna medida para adaptar mejor la capacidad económica del sujeto perceptor de una pensión compensatoria, ya que en algunas ocasiones la situación financiera del mismo será muy difícil tras una separación o divorcio, lo que puede conllevar a una falta real de riqueza que la Ley no contempla, por lo que debería existir alguna forma de evitarlo. Así, se podría pensar en una exención de la pensión recibida, si el sujeto no demuestra tener más rendimientos en cierta cuantía o una reducción específica al rendimiento neto del art. 20 de la Ley del Impuesto.

En cambio, como es bien sabido, la situación del sujeto pagador de dicha pensión compensatoria está, en cierto modo, sobreprotegida, pues el art. 55 de la Ley le permite reducir su base imponible con el importe total de la pensión sufragada, sin ninguna limitación salvo la cuantía total de dicha base, lo que desemboca, en la práctica a que las rentas más altas se beneficien más de dicha reducción que las más bajas; en efecto, como dispone el artículo 50 de la Ley del Impuesto: "La base liquidable general estará constituida por el resultado de practicar en la base imponible general, exclusivamente y por este orden, las reducciones a que se refieren los artículos 51, 53, 54, 55 y disposición adicional undécima de esta Ley, sin que pueda resultar negativa como consecuencia de dichas disminuciones", lo que conduce a que si la base imponible del sujeto es inferior a la pensión entregada, no podrá reducir en su totalidad la misma, lo que hace, de facto que los contribuyentes con menores rentas se vean perjudicados al no poder descontarlas, mientras los que sí disponen de ellas las absorberán en su integridad.

21 Desde un punto de vista genérico, vid. RODRÍGUEZ RAMOS, M.: "El régimen fiscal de la dependencia", Revista xuridica da Universidade de Santiago de Compostela, núm. 2, 2008, págs. 187 y ss.; DELGADO GARCÍA, A.M. y OLIVER CUELLO, R.: “Aspectos fiscales de la discapacidad y la dependencia", en la Obra Colectiva: Hacia una visión global de los mecanismos jurídico-privados de protección en materia de discapacidad, El Justicia de Aragón, Zaragoza, 2010, págs. 545 y ss. y GUERVÓS MAÍLLO, M.A.: "Medidas fiscales sobre la dependencia y la discapacidad en la Unión Europea y en España", Noticias de la Unión Europea, núm. 303, 2010, págs. 109 y ss. 
Es claro, por lo tanto, el trato diferencial entre rentas, determinándose un carácter ciertamente regresivo del impuesto en este caso, a la par que poco respetuoso con la capacidad económica.

Por otro lado, el art. 19.2.e) declara como gasto deducible de los rendimientos del trabajo "Los gastos de defensa jurídica derivados directamente de litigios suscitados en la relación del contribuyente con la persona de la que percibe los rendimientos, con el límite de 300 euros anuales".

De nuevo, como en el supuesto anterior se está perjudicando al contribuyente con rentas inferiores, porque al establecerse una limitación de 300 euros se está obligando a soportar a la renta del trabajador, que está litigando contra su antiguo empresario, el exceso de costes de representación en un proceso judicial y que, ciertamente, serán en muchos casos superiores a dicha cuantía. Para el trabajador con ingresos superiores el esfuerzo económico será menor, lo que conduce otra vez a que podamos pensar que se está obrando de forma inversamente proporcional a la capacidad económica de los contribuyentes, pues el que más tiene notará menos el coste del litigio que el que no alcanza un rendimiento muy elevado.

Siguiendo con nuestro examen, podemos citar el art. 24, que obliga a declarar como rendimiento en caso de parentesco por cesión de bienes inmuebles el porcentaje derivado de las imputaciones de rentas inmobiliarias del art. 85 de la Ley, lo que nos sitúa claramente ante la problemática de este trabajo; en efecto, en algunos casos -y más en la época de crisis de estos momentos- la única solución para algunas familias que han perdido sus viviendas por impagos de créditos hipotecarios es volver a convivir con sus familiares, principalmente sus ascendientes. Con esta medida tributaria del art. 24, se está haciendo recaer un gravamen sobre una riqueza inexistente, pues el propietario de una vivienda en la que ahora residen más personas habrá visto su capacidad económica disminuida, en vez de ampliada, al no recibir mayores ingresos y subir efectivamente sus gastos por ese uso múltiple del inmueble ${ }^{22}$.

Además, al obligar a tributar con carácter mínimo de acuerdo con el art. 85, no se les permite descontar ningún gasto deducible, lo que evita la modulación del gravamen conforme a la capacidad económica del contribuyente y se está impidiendo la correcta aplicación del mismo. Evidentemente, habrá casos en que se estará encubriendo un alquiler que no se declara por parte de parientes que, incluso, disfrutarán gratuitamente de una vivienda, pero no en una gran mayoría de supuestos en los que es la necesidad vital la que empuja a dichas situaciones.

En relación a los gastos deducibles de los rendimientos de capital mobiliario, el art. 26 solo incluye en su apartado 1.a) los gastos de administración y depósito de valores negociables, habiéndose suprimido los derivados de la custodia y mantenimiento de

22 En este sentido: RUIZ GARIJO, M.: Los rendimientos de capital inmobiliario en el nuevo $I R P F$, Edersa, Madrid, 2003, págs. 24 y ss. y MARTíNEZ AZUAR: "Rendimientos del capital inmobiliario e imputaciones de renta inmobiliarias tras la Ley 35/2006 del IRPF", Técnica Tributaria, núm. 80, 2008, págs. 81 y ss. 
cuentas bancarias y similares; en cambio, sí que se contenían en la regulación de 1978 (art. 17.3.1.a)) y de 1991 (art. 39.Uno), respectivamente, de las Leyes reguladoras del Impuesto sobre la Renta de las Personas Físicas, si bien se incluían genéricamente en la expresión "gastos de administración y custodia", aunque sin añadir, como hace la disposición actual ninguna concreción respecto a que sean los derivados de valores negociables, lo que permitía una interpretación más amplia y, a nuestro juicio, más respetuosa con la capacidad económica del precepto.

Incluso podemos ir más allá y advertir que si se examina detenidamente la legislación vigente, se comprueba que los gastos por comisiones de las entidades de crédito sí pueden ser deducibles para los contribuyentes que ejerzan actividades económicas, pues se les permite descontar en los regímenes de estimación directa todos los gastos necesarios para obtener los rendimientos, al remitirse el art. 28 de la Ley 35/2006 a la regulación correspondiente del Impuesto sobre Sociedades que consiste en los arts. 15 y 16 de la Ley 27/2014, de 27 de noviembre, de la que nos ocuparemos en el epígrafe siguiente. Dichos preceptos no excluyen dichos gastos, salvo que sean de muy elevada cuantía, lo que redunda en una cierta vulneración no solo de la capacidad económica de los contribuyentes que vean mermados sus ingresos por rendimientos de capital mobiliario al pagar las mentadas comisiones, sino que también se puede vulnerar el principio de igualdad, cuando se les permite descontar las cuantías a las personas físicas que ejercen actividades empresariales y profesionales, mientras que a los demás, no, cuando muchos contribuyentes tendrán un efectivo nivel de riqueza muy inferior a los empresarios y profesionales.

De forma parecida, el art. $30.2 .5^{\mathrm{a}}$ permite como gasto deducible para los rendimientos de actividades económicas en régimen de estimación directa "las primas de seguro de enfermedad satisfechas por el contribuyente en la parte correspondiente a su propia cobertura y a la de su cónyuge e hijos menores de veinticinco años que convivan con él. El límite máximo de la deducción será de 500 euros por cada una de las personas señaladas anteriormente".

Dejando al margen la elevación de dicho límite a 1.500 euros para el caso de personas con discapacidad, hecho que conlleva otras valoraciones diferentes a las que efectuamos en el presente trabajo, lo que sí llama la atención es que se permita la deducción de dichos gastos para los familiares del empresario o profesional persona física y no se permita en la normativa del Impuesto dicha medida para los mismos familiares de un sujeto que gane rendimientos del trabajo. Evidentemente no cuestionamos la deducción para el propio contribuyente cuando tienen el carácter obligatorio, como sucede anteriormente en el mismo art. 30.2.1 a , pero sí que habría que dudar cuando se le permite deducir, a mayores, las cuantías de dichos seguros, máxime cuando tengan carácter voluntario, pues esta posibilidad está vetada para los sujetos que obtienen rendimientos del trabajo; en efecto, estos últimos pueden deducirse las cotizaciones a la Seguridad Social o derechos pasivos, pero no los seguros voluntarios de enfermedad que sí se permiten para los contribuyentes que ejerzan actividades económicas. Si a ello se añade que no solo para el propio sujeto pasivo, sino también para su cónyuge e hijos menores de veinticinco años, encontramos un nuevo problema de respeto al principio constitucional que nos ocupa, pues parece que debe protegerse más la riqueza del empresario que la del trabajador 
y, más todavía, cuando no se subordina el efectivo descuento de las cantidades de los familiares a ningún otro requisito, pues no se prevé el hecho de que dependan para subsistir de nadie, salvo el condicionante de la convivencia, que no trae consigo necesariamente la dependencia económica.

En definitiva, se trata de un nuevo supuesto dudoso en el que se está gravando una supuesta mayor capacidad económica - la del trabajador que no puede descontar gastos de seguros de enfermedad de sus familiares - frente a una menor riqueza en la figura del empresario o profesional que sí está habilitado para ello por la Ley del Impuesto $^{23}$. No pensamos que ello sea acorde al precepto constitucional, ni incluso al principio de igualdad tributaria que excede los límites de este estudio.

En otro orden de cosas, el art. 42.3.f) declara exentas "la entrega a los trabajadores en activo, de forma gratuita o por precio inferior al normal de mercado, de acciones o participaciones de la propia empresa o de otras empresas del grupo de sociedades, en la parte que no exceda, para el conjunto de las entregadas a cada trabajador, de 12.000 euros anuales, siempre que la oferta se realice en las mismas condiciones para todos los trabajadores de la empresa, grupo o subgrupos de empresa".

Esta previsión, que tiene su origen y razón de ser en la entrega de opciones o de parte de la empresa para sus altos directivos, denota un grave cumplimiento del principio de capacidad económica, pues, permite abonar retribuciones en especie del trabajo sin tener que tributar por ellas $\mathrm{y}$, si se desciende al mundo de la práctica, se llega a la fácil conclusión de que los beneficiados no serán los trabajadores de menores ingresos ${ }^{24}$; en efecto, salvo en contadas ocasiones - piénsese en el caso de cooperativas de trabajadores en las que se les puede retribuir de esta forma- lo habitual será que seguirán siendo los citados directivos - con una gran capacidad o riqueza normalmente- los que se beneficien de esta exención -si bien limitada a los 12.000 euros anuales-. Con ello, se estará operando de forma inversa a la máxima que nos ocupa, pues se está otorgando una rebaja fiscal a quien más debería tributar en función de su riqueza.

Por último, debemos llamar la atención sobre el art. 85, relativo a la imputación de rentas inmobiliarias que, como es bien sabido, hace tributar a los inmuebles urbanos vacíos por un porcentaje de su valor catastral. Esta medida nos parece que vulnera claramente la capacidad económica del contribuyente, pues se está haciendo derivar una renta que es claramente inexistente y que, solo bajo la nota de una imputación de renta - presunta en todo caso- $^{-}$y claramente potencial se puede soslayar el inconveniente de hacer recaer el gravamen sobre la mera titularidad de bienes y no

23 Como es lógico una cuestión distinta es la posibilidad de que sea el propio empresario el que pague las primas de los seguros de enfermedad a sus trabajadores o sus familiares, hecho que sí está previsto en la Ley en el art. 42.3.c) que los considera retribuciones en especie exentas. Pero lo que no está contemplado es que sea el trabajador el que las abone y ello no se considera gasto deducible como hemos comprobado en el texto.

24 Sobre este tema: MALVÁREZ PASCUAL, L.A.: "Régimen fiscal de la entrega a los trabajadores de acciones de la empresa", Revista de Contabilidad y Tributación, núm. 169, 1997, págs. 139 y ss. 
sobre sus frutos, que es el objetivo primordial del Impuesto sobre la Renta de las Personas Físicas ${ }^{25}$.

Se podría argumentar, no obstante, que el objetivo de este precepto es incentivar a que gran parte de los inmuebles que se encuentran sin utilizar afloren al mercado inmobiliario por medio de su venta o arrendamiento, pero dicha justificación no justifica, a nuestro parecer, la onerosidad del tributo; ello es así porque -y más en los tiempos de crisis inmobiliaria-, la titularidad de una finca o construcción urbana hoy en día puede ser más una fuente de gastos y obligaciones que de ingresos -aunque sean potenciales-; para ello basta con pensar en que incluso se podría estar rondando una doble imposición de facto, al incidir sobre la mera titularidad de un inmueble -imputándole una renta presunta- al igual que hace el Impuesto sobre el Patrimonio en su art. 10.

En la práctica hallaremos situaciones concretas de todos los tipos y, para el supuesto de personas que tengan los pisos cerrados con un mero fin especulativo, creemos que ya es suficiente con que contribuyan en el Impuesto mediante la ganancia patrimonial que hipotéticamente pueden obtener cuando los enajenen; en cambio, para los que hayan obtenido los bienes con otras causas: herencia, compra con el fin de habitarlos en un futuro, el art. 85 les está haciendo tributar por una riqueza que no es propiamente una adquisición de una renta -que es el objetivo del Impuesto- de manera que no solo se está incidiendo en una capacidad no existente, sino que tampoco se modula la cuantificación del tributo por medio de la misma. En este último sentido piénsese en que -al ser técnicamente una imputación de renta- no se permite ningún gasto deducible al contribuyente -como podría ser el Impuesto sobre Bienes Inmuebles o los gastos de comunidad o reparación- lo que impide más todavía esa modulación del gravamen a través de la tantas veces citada capacidad económica del sujeto pasivo.

En definitiva, estos ejemplos que hemos indicado suponen una visión de los problemas que la aplicación estricta del principio constitucional suscita en el impuesto personal sobre la renta y ello nos permite reflexionar sobre el efectivo respeto y vigencia del mismo.

\section{B) Impuesto sobre Sociedades}

A continuación vamos a utilizar la misma metodología para el tributo que grava la renta de las personas jurídicas residentes en España; en consecuencia, de un análisis de la ley 27/2014, de 27 de noviembre, deducimos los siguientes problemas de respeto al principio de capacidad económica:

Primero, en el art. 9.3.c), cuando establece la exención parcial en el tributo para "los colegios profesionales, las asociaciones empresariales, las cámaras oficiales y los

25 Para un mayor detalle del tema de las viviendas desocupadas y su tributación en normas anteriores a la vigente, véase: HERRERA MOLINA, P.M.: Capacidad económica y sistema fiscal. Análisis del ordenamiento español a la luz del Derecho alemán, Marcial Pons, Madrid, 1998, págs. 211 y ss. 
sindicatos de trabajadores". En este caso no pensamos que sea la misma situación la de las diferentes entidades que se mencionan en el precepto, pues la motivación para obtener la exención citada es muy distinta en el caso de un sindicato que en el de una asociación de empresarios; para este último supuesto, no creemos que exista una auténtica falta de capacidad económica -que motiva el beneficio fiscal- pues en muchas ocasiones dichas asociaciones tendrán una finalidad lucrativa, no altruista, que es la que en el fondo sirve de soporte argumental a todo. En consecuencia, se está alterando la razón de ser de la máxima constitucional.

Por otra parte, para los colegios profesionales y las cámaras oficiales, tampoco hallamos un fundamento claro de su reducción tributaria, ya que disponen de recursos suficientes para atender a sus finalidades - piénsese en los visados colegiales y en el recurso cameral permanente que se atribuyen las citadas cámaras- que incluso denotan una mayor riqueza que en otro tipo de sociedades. Por ello se está actuando, a nuestro parecer, en relación inversa a la búsqueda de medios económicos suficientes para contribuir.

En segundo término, el art. 13.1.1 ${ }^{\circ}$, cuando excluye de deducción las pérdidas por deterioro por posibles insolvencias de "los créditos adeudados por entidades de derecho público, excepto que sean objeto de un procedimiento arbitral o judicial que verse sobre su existencia o cuantía".

Dejando al margen el hecho de la admisión como pérdida por deterioro si hay dicho procedimiento relativo a su existencia o cuantía, lo que, caso de no aplicarse, pondría en tela de juicio la propia naturaleza de la deuda en cuestión, lo cierto es que las situaciones de insolvencia de los entes públicos ha motivado en los últimos años de crisis económica muchísimas dificultades financieras a los operadores privados del mercado; en consecuencia, la figura de la deducción de la provisión por insolvencias tiene su fundamento en evitar la tributación por una renta que no se ha recibido efectivamente y hay pocas posibilidades de obtenerse a corto o medio plazo.

Se podría pensar que los entes públicos - máxime después de las medidas aprobadas últimamente para garantizar (o tratar de garantizar) el pago de sus deudas- siempre consiguen allegar recursos para hacer frente a sus obligaciones, lo que excluiría a sus créditos de los que estamos tratando y sí estaría plenamente justificada entonces la ausencia de provisión; sin embargo, la realidad es muy diferente, pues los casos de ausencia de liquidez y de suspensión de pagos de ciertas entidades públicas -como los Ayuntamientos- han provocado que muchas empresas dependientes de sus abonos -al ser sus principales clientes - hayan tenido dificultades e, incluso, hayan debido dar de baja su actividad.

Todo ello nos entronca con el tema que nos ocupa, porque las empresas privadas que han debido declarar como ingresos en su Impuesto sobre Sociedades las cantidades a cobrar de las entidades públicas se han visto mermadas en su capacidad económica al tener que tributar por algo que no han recibido -ya que deben atenerse al criterio del devengo, no del cobro efectivo que, como es bien sabido, sí se permite en el Impuesto sobre el Valor Añadido-, y al no poder descontar como gasto las provisiones técnicas por insolvencias, la riqueza gravada ha sido no potencial, sino irreal. Además, la forma 
de modular en este caso la base imponible del gravamen se ha visto alterada por la elevación de la misma en la cuantía de las cantidades adeudadas por los entes públicos, lo que influye en el resto de magnitudes y procedimientos liquidatorios que deben tener en cuenta dicha base. En definitiva, sería preferible que se admitiese la pérdida por deterioro en este caso, evitando así este riesgo de violentar la capacidad contributiva real de las sociedades ${ }^{26}$.

Otro problema se encuentra en el art. 14.3, que declara no deducibles los gastos asociados a provisiones que sean "relativos al riesgo de devoluciones de ventas". Sin embargo, si se reflexiona detenidamente sobre este tema se puede llegar a la conclusión de que un elevado volumen de devoluciones puede afectar muy negativamente al margen de maniobra de una empresa, de forma que disminuya sensiblemente su riqueza imponible. Por lo tanto, si no se permite deducir como gasto los costes de aseguramiento de dichas devoluciones, se estará corriendo el riesgo de hacer tributar a una sociedad por unas entregas de bienes que se han efectuado en dos ocasiones: en la primera venta y en la segunda aportación de los bienes ya reparados o sustitutivos. Bien es verdad que se podría pensar que las mercancías devueltas por los clientes se pueden retornar al proveedor original de la empresa para que proceda a su sustitución o se reintegre el coste de las mismas, pero ello sucederá cuando la sociedad se dedique a la compraventa de bienes sin transformación en su industria; en el supuesto de que no sea así -es decir, que la empresa realice alteraciones en los bienes o, sea directamente el fabricante- el menoscabo en su capacidad económica se ve más claramente, porque los costes de producción o fabricación serán más elevados si se tiene que reparar o sustituir dichas mercancías. De este modo el fabricante no podrá recuperar parte de la inversión realizada al tener que afrontar el sobrecoste de las reparaciones, ya que no puede -como es lógico- repercutirlo al cliente que ya ha tenido suficiente perjuicio con la avería que ha soportado. Esa mayor carga de gasto hace que la capacidad económica real de la empresa sea inferior a la que está teniendo que declarar en el Impuesto, inconveniente que podría paliarse mediante la oportuna deducción de los gastos de aseguramiento de tales reparaciones.

A su vez, el art. 15.e) considera gasto no deducible los donativos y liberalidades, exceptuándose de esta calificación "las retribuciones a los administradores por el desempeño de funciones de alta dirección, u otras funciones derivadas de un contrato de carácter laboral con la entidad".

La posible vulneración del principio de capacidad económica se comprueba en el hecho de que las grandes empresas -y por ende, las de mayor riqueza- dispondrán de mejores fórmulas para retribuir a sus altos directivos, mientras que las de menos fortaleza económica no alcanzarán a pagarles por medio de estas figuras, que pueden llegar incluso a revestir la forma de retribuciones en especie encubiertas. Como es lógico pensar, los donativos o liberalidades que reciban los dirigentes de grandes empresas siempre serán mucho más cuantiosos que los de las de tamaño más reducido,

26 Para un mayor detalle: GONZÁLEZ GARCÍA, A.L.: "Las insolvencias en el Impuesto sobre Sociedades”, Hacienda Pública Española, núm. 47, 1977, págs. 189 y ss. y ROJÍ CHANDRO, L.A. y ROJÍ PÉREZ, S.: "Las empresas de reducida dimensión en el Impuesto sobre Sociedades: incentivos fiscales”, Revista Contable, núm. 52, 2017, págs. 24 y ss. 
de manera que se estará exceptuando de gravamen -al considerarse gasto deduciblelos que reciban tales administradores y así se actúa de forma inversamente proporcional a la riqueza de una entidad; en efecto, a mayor capacidad de pago a sus administradores, la cantidad deducible será superior, con lo que, las pequeñas empresas, que no puedan fijar una retribución complementaria de este tipo a su consejo de administración, se verán perjudicadas por no poder ampararse por esta deducción ${ }^{27}$.

Otro supuesto se encuentra, a nuestro juicio, en el art.19.3, cuyo tenor literal indica: "El perceptor de cantidades sobre las que deba retenerse a cuenta de este Impuesto computará aquéllas por la contraprestación íntegra devengada.

Cuando la retención no se hubiera practicado o lo hubiera sido por importe inferior al debido, por causa imputable exclusivamente al retenedor, el perceptor deducirá de la cuota la cantidad que debió ser retenida".

En este supuesto es clara la divergencia entre la capacidad económica real del contribuyente y la que efectivamente se declara en el Impuesto; en efecto, si no se ha llevado a cabo la retención oportuna o se haya realizado en una cuantía inferior, el contribuyente se ve "premiado" con la posibilidad de deducir la misma, aunque no haya sido real, con lo que estará restando en su cuota un pago a cuenta que no ha satisfecho en realidad. El resultado de todo ello será que se está tributando por una menor cuantía que la que sería normal, a pesar de una elevación al íntegro de los ingresos en la base imponible -operada a través de un ajuste fiscal positivo-, que, como es bien sabido, un aumento de base imponible con la correlativa deducción en la cuota por el mismo concepto no siempre tiene un carácter neutral en la mecánica impositiva. Esto último se comprueba fácilmente al pensar en las deducciones en la cuota-que actúan antes de los descuentos por pagos a cuenta- que tienen como límite la cuantía total de la cuota líquida.

Por lo tanto, debería haberse optado por acudir a la solución que la norma prevé para el caso de retenciones efectuadas por entes públicos, que consiste -en el mismo precepto- en indicar que "en el caso de retribuciones legalmente establecidas que hubieran sido satisfechas por el sector público, el perceptor sólo podrá deducir las cantidades efectivamente retenidas". Esto da más neutralidad a la mecánica del tributo al mismo tiempo que, a nuestro parecer, no afecta al principio de capacidad económica.

En cuanto a las reducciones en la base imponible del tributo, el art. 23 establece una del 60 por ciento para las "rentas procedentes de la cesión del derecho de uso o de explotación de patentes, dibujos o modelos, planos, fórmulas o procedimientos secretos, de derechos sobre informaciones relativas a experiencias industriales, comerciales o científicas".

27 Vid.: GARCÍA NOVOA, C.: "La deducibilidad de las retribuciones a los administradores en el Impuesto de Sociedades", Quincena Fiscal, núm. 8, 2009, págs. 57 y ss. y MAGRANER MORENO, F.J.: "Un "esperado" giro jurisprudencial en torno a la calificación de las retribuciones de los administradores como gasto en el Impuesto sobre Sociedades", Tribuna Fiscal, núm. 256, 2012, págs. 8 y ss. 
La razón de ser de este beneficio fiscal estriba en la protección que se quiere dar a la propiedad intelectual y a la entrada en el mercado de este tipo de activos intangibles, con lo que se les da un trato de favor para que afloren al mismo y se cedan para su explotación efectiva. No obstante el propio precepto en el apartado 1.b) prevé que debe cumplirse el requisito de "que el cesionario utilice los derechos uso o de explotación en el desarrollo de una actividad económica y que los resultados de esa utilización no se materialicen en la entrega de bienes o prestación de servicios por el cesionario que generen gastos fiscalmente deducibles en la entidad cedente, siempre que, en este último caso, dicha entidad esté vinculada con el cesionario".

Con este inciso el artículo está limitando la efectiva venta de bienes o prestaciones de servicios del cesionario al cedente consecuencia de productos que tengan su origen en el activo intangible y solo para el supuesto de que sean entidades vinculadas.

Todo ello nos parece muy bien, pero no es tan claro el hecho de que solamente se haga tributar los derechos de cesión en un 40 por ciento, lo que da lugar a que la riqueza por la que tiene que declarar el cedente es muy inferior a la realmente percibida, sobre todo en los casos de grandes multinacionales que ceden la explotación de sus patentes, planos, fórmulas o procedimientos secretos; así se estará gravando una capacidad económica inferior a la real.

Creemos que este beneficio fiscal se debería mantener para personas físicas o pequeñas empresas que hayan realizado una invención o el desarrollo de un nuevo procedimiento, pero se debería limitar para entidades de mayor envergadura.

Una novedad incluida en el art. 25 por la Ley 27/2014 es la relativa a la reserva de capitalización, que consiste en permitir a "los contribuyentes que tributen al tipo de gravamen previsto en los apartados 1 o 6 del artículo 29 de esta Ley tendrán derecho a una reducción en la base imponible del 10 por ciento del importe del incremento de sus fondos propios". Con esta medida se ha intentado motivar que las entidades destinen mayores cantidades a nutrir su capital y reservas, evitando la descapitalización que frecuentemente se produce en épocas de crisis económica ${ }^{28}$.

Sin embargo, si se atiende a la cuantía de la efectiva reducción, que asciende al citado 10 por ciento de dicho incremento de los fondos propios, se comprueba que ello da lugar a un método de reducción de la base impositiva que podríamos llegar a calificar de regresivo, pues aumenta proporcionalmente a medida que son mayores las cantidades destinadas a dicho fin. Asimismo, el propio art. 25 establece un segundo límite cuando indica que "en ningún caso, el derecho a la reducción prevista en este apartado podrá superar el importe del 10 por ciento de la base imponible positiva del período impositivo previa a esta reducción, a la integración a que se refiere el apartado 12 del artículo 11 de esta Ley y a la compensación de bases imponibles

28 En este sentido: MÍNGUEZ CONDE, J.L.: "La reserva de capitalización en la Ley 27/2014, de 27 de noviembre, del Impuesto sobre Sociedades", Quincena Fiscal, núm. 13, 2015, págs. 113 y ss. y MALVÁREZ PASCUAL, L.A. y MARTÍN ZAMORA, M.P.: "Las nuevas reducciones de la base imponible en el Impuesto sobre Sociedades: las reservas de capitalización y nivelación”, Contabilidad y Tributación, núm. 383, 2015, págs. 109 y ss. 
negativas". Con ello se está aplicando un doble límite que también beneficiará a las bases más elevadas, mientras que a las más bajas se les está recortando claramente el ámbito del beneficio fiscal.

Lo indicado es fácilmente deducible si se piensa en cualquier entidad que, sin ser de reducida dimensión (a las que el artículo 105 de la Ley permite una reducción en la base denominada reserva de nivelación y que actúa de forma parecida a la que nos ocupa), no ha generado una cifra de negocios muy elevada como una gran empresa; en este caso, las grandes empresas podrán pagar un 10 por ciento menos de tributo, lo que, en razón de las elevadas cantidades que manejan dan lugar a una rebaja del gravamen que las beneficia mucho más que las que no tenga un volumen tan alto de negocios.

Este inconveniente y posible poco respeto a la capacidad económica, pues se está beneficiando al que mayores niveles de renta posee, se podría haber paliado mediante la inclusión de un límite concreto basado en una cantidad máxima a descontar -un fijo de $\mathrm{x}$ euros- en lugar de un tope genérico sobre un porcentaje de la misma base imponible. Como venimos exponiendo en estas páginas, el legislador presenta poco cuidado y delicadeza con la máxima constitucional que nos interesa.

Otro problema es la existencia en el art. 29 de un tipo de gravamen del 1 por ciento para las entidades de inversión de capital variable, los fondos de inversión de carácter financiero, las sociedades de inversión inmobiliaria, los fondos de inversión inmobiliaria y el fondo de regulación del mercado hipotecario.

No creemos que hagan falta muchos comentarios o explicaciones para demostrar cómo no se tiene en cuenta la capacidad económica de dichos contribuyentes a la hora de determinar su cuota tributaria; en efecto, como se habrá deducido con facilidad, los titulares, en la mayoría de las ocasiones, de los fondos antedichos serán personas físicas o jurídicas de elevada riqueza que utilizan dichas entidades para poner a su nombre sus bienes y valores y de esa forma evitar el gravamen patrimonial de los mismos. De esta forma se está evitando que personas con una fuerte capacidad económica se vean favorecidos frente a los que tienen menor valor o número de bienes que no pueden acceder, en ocasiones, a dichas instituciones. La cuantificación del Impuesto sobre Sociedades se está, por lo tanto, disminuyendo en función de la mayor riqueza, hecho que atenta a la capacidad económica e, incluso, dotando al gravamen de una cierta regresividad.

Por último, en el art. 34 se establece una bonificación en la cuota íntegra del Impuesto por la prestación de servicios públicos locales que alcanza el 99 por ciento de la parte de dicha cuota proveniente de esos beneficios.

Evidentemente el objetivo perseguido por el legislador es promover que las empresas opten por obtener los concursos públicos para convertirse en concesionarios para prestar dichos servicios públicos pero, con la fórmula arbitrada para conseguirlo se está vaciando de contenido la cuota resultante de los beneficios que con ello se obtenga, de tal forma, que, a pesar de conseguir unos ingresos -que en ocasiones son más regulares en su devengo que en el tráfico mercantil privado- se está tributando 
exclusivamente por el 1 por ciento de su cuota correspondiente. Por otro lado se podría pensar que en las épocas de dificultades financieras de los entes públicos dichas empresas concesionarias debería devengar las cantidades facturadas principalmente a los Ayuntamientos y que, éstos, tardarían un tiempo en realizar los pagos, con lo que esta bonificación estaría plenamente justificada. Esta objeción, en cambio, se puede soslayar si se permite dotar como pérdida por deterioro por insolvencias los créditos frente a las entidades locales que, como hemos visto, no se admiten en el artículo 13.1.1 ${ }^{\circ}$ de la Ley del Impuesto, hecho que no está en la mente del legislador actual, con lo que, las empresas que cobren efectivamente tendrán una fuerte riqueza por la que están exonerados de contribuir.

En conclusión, al igual que hemos comprobado en el Impuesto sobre la Renta de las Personas Físicas, en el Impuesto sobre Sociedades hemos hallado una serie de supuestos en los que el respeto al principio de capacidad económica es, cuando menos, dudoso, tanto en el aspecto de tenerlo en cuenta para gravar una determinada situación, como para apoyarse en él para modular la cuota a pagar en concepto de tributo.

\section{C) Impuesto sobre Sucesiones y Donaciones}

Cerramos este apartado de nuestro trabajo haciendo una breve mención a tres artículos de la Ley 29/1987, de 18 de diciembre del Impuesto sobre Sucesiones y Donaciones que pensamos que entran en fricción con el correcto respeto a la máxima constitucional que comentamos.

En primer lugar, el art. 15 valora el ajuar doméstico del causante indicando que "formará parte de la masa hereditaria y se valorará en el tres por ciento del importe del caudal relicto del causante, salvo que los interesados asignen a este ajuar un valor superior o prueben fehacientemente su inexistencia o que su valor es inferior al que resulte de la aplicación del referido porcentaje".

La razón de ser de este precepto es evitar la engorrosa tarea de cuantificar los diversos bienes que pueden integrar el ajuar doméstico y que puede conducir a valoraciones erróneas y a cierto grado de fraude fiscal; sin embargo, en su empeño el legislador ha ido demasiado lejos, pues ha establecido una presunción iuris tantum que sitúa la cuantificación en un porcentaje global basado en el propio caudal relicto de la persona fallecida, lo que prescinde casi completamente de la verdadera riqueza o valoración concreta del citado ajuar.

En este sentido, en aras de una mayor simplificación de las tareas liquidatorias se ha hecho depender de forma directa este método de valoración de la cuantía global de los bienes y derechos transmitidos por la herencia, minorados en las cargas, deudas y gastos deducibles. Pero no es claro que un porcentaje de ese neto patrimonial que se ha de repartir entre los causahabientes del fallecido constituya efectivamente los enseres propios de la figura indicada, con lo que en muchas ocasiones se estará gravando una capacidad económica no real e, incluso, ficticia. 
Bien es cierto que se introduce como presunción que permite prueba en contrario, pero piénsese en la dificultad para conseguir desvirtuar la misma, que precisaría de una concreta evaluación de cada uno de los bienes del ajuar doméstico, hecho que redundaría, en no pocos casos, en una dificultad importante, tanto de consensuar un valor real a los bienes, como de realizar el método correcto para ello, pues muchos de los enseres tendrán cierta antigüedad y será muy difícil cuantificarlos según parámetros actuales.

Peor todavía es la previsión legal de que los propios interesados asignen un valor superior al citado ajuar que el 3 por ciento previsto en la norma, ya que, por su propio interés, los causahabientes preferirán dejar el porcentaje en lugar de declarar una cantidad más elevada que, lógicamente, les perjudicaría a la hora del abono de la cuota correspondiente. Los futuros contribuyentes del Impuesto optarán por dejar la presunción legal y así evitar una tarea engorrosa de medición, al mismo tiempo que más onerosa a la hora de satisfacer el tributo. De esta forma, se está, una vez más, haciendo medir una base imponible en un criterio que se aparta de la riqueza real de los obligados tributarios.

En segundo término, el art. 20.2.b) permite una reducción en la base imponible del "100 por 100, con un límite de 9.195,49 euros, a las cantidades percibidas por los beneficiarios de contratos de seguros sobre vida, cuando su parentesco con el contratante fallecido sea de cónyuge, ascendiente, descendiente, adoptante o adoptado".

La posible vulneración a la máxima constitucional que analizamos se advierte al reflexionar acerca de la escasa flexibilidad con que se arbitra la reducción citada; tanto es así porque no se distingue ningún tipo de discriminación en la cuantía a descontar en función del grado de riqueza del beneficiario del seguro de vida, dejando al margen los coeficientes correctores que sobre la totalidad de la cuota íntegra del tributo establece el artículo 22.2 de su Ley reguladora. Esos coeficientes actúan sobre el global de la cuota, es decir, sobre todo el caudal relicto, sin hacer ningún tipo de distinción en la fuente concreta de lo recibido, hecho que pensamos que es lógico por su propia naturaleza de adaptar el gravamen a la cuantía del patrimonio preexistente del contribuyente; por ello, no creemos que sean útiles para adaptar las cantidades concretas que deba recibir un beneficiario de un seguro de vida, aun cuando el propio artículo 22.2 prevea aplicarlos para dichos beneficiarios. El problema no estriba en la aplicación del coeficiente, sino en que la adaptación que realiza para los sujetos con un patrimonio preexistente superior a 4.020.770,98 euros en el Grupo I y II de parentesco (los más allegados), hace multiplicar la cuota por 1,2 , hecho que no supone un incremento fiscal excesivo para una gran fortuna, la cual, ya se habrá beneficiado del descuento en la base imponible.

El razonamiento anterior todavía se puede reforzar más si se piensa en las importantes sumas que hay que abonar en concepto de primas a las compañías aseguradoras en este tipo de seguros, máxime cuando la edad del asegurado es elevada, lo que conducirá a que solamente las rentas más altas puedan afrontar su desembolso. En consecuencia, introducir una reducción sin mayor distingo sobre la capacidad 
económica real tanto del asegurado (la persona fallecida) como el beneficiario (su causahabiente) está beneficiando a dichas rentas altas a las que prescindir del precio de la prima les supondrá un menor esfuerzo económico que a las de menor capacidad económica, con lo que se estará haciendo pagar menor tributo al que demuestra más riqueza.

Sería preciso, como un medio de evitar este riesgo de vulneración del principio constitucional, que la aplicación del coeficiente por patrimonio preexistente se aplicase individualizadamente en cada reducción de la base imponible y así se adaptaría mejor a la situación económica del contribuyente.

En último lugar destaca el art. 21.2, que incluye la tarifa del tributo, cuyo tipo marginal puede llegar al 34 por ciento y cuyas cuotas íntegras pensamos que son excesivas para caudales hereditarios que no superan los 70.000 euros, en los cuales se puede alcanzar el 15 por 100 de tipo marginal. Esto provoca que muchas personas que reciben, por ejemplo, bienes inmuebles en la herencia -y que no constituyan su vivienda habitual que estaría en parte exenta-, deban afrontar un coste impositivo en algunas circunstancias prohibitivo, pues al citado 15 por ciento se añadiría el impuesto municipal sobre plusvalías de los terrenos urbanos. Si la adquisición se produce después de mucho tiempo transcurrido desde la anterior transmisión, dicha plusvalía será muy importante, lo que, en los tiempos de crisis económica, puede conducir a tener que enajenar - o mal vender- los citados inmuebles para pagar los tributos, lo que mueve a pensar en que además de gravarse de manera exagerada una capacidad económica no tan elevada, se estaría llegando a conculcar el principio de no confiscatoriedad.

\section{BREVE ANÁLISIS DE LA SENTENCIA EL TRIBUNAL CONSTITUCIONAL DE 11 DE MAYO DE 2017 EN RELACIÓN CON EL GRAVAMEN DE LAS PLUSVALÍAS EN EL ÁMBITO LOCAL}

Como colofón a todo lo examinado en páginas anteriores relativo al respeto de la normativa tributaria vigente al principio de capacidad económica, nos resta analizar la reciente Sentencia del Tribunal Constitucional 59/2017, de 11 de mayo, por la que se declaran inconstitucionales algunos preceptos del Texto Refundido de la Ley Reguladora de las Haciendas Locales, aprobado por Real Decreto Legislativo 2/2004, de 5 de marzo.

El fallo parte de una cuestión de inconstitucionalidad promovida por un Juzgado de lo Contencioso-Administrativo de Jerez de la Frontera en el que se duda sobre la vulneración al principio que nos ocupa en el art. 107 del citado Texto Refundido, en lo que se refiere a la forma de cuantificar la base imponible del Impuesto municipal sobre el Incremento de Valor de los Terrenos de Naturaleza Urbana ${ }^{29}$.

29 El problema no es de ahora, como puede comprobarse en la lectura de: ALBIÑANA GARCÍA-QUINTANA, C.: "Génesis y trayectoria del Impuesto Municipal de Plusvalía", Revista de Estudios de la Administración Local y Autonómica, núm. 228, 1985, págs. 609 y ss.; ÁlVAREZ ARROYO, F.: Impuesto municipal sobre el incremento de valor de los 
La argumentación jurídica del Auto que plantea la cuestión reconoce que la norma solo admite como resultado del impuesto la existencia de cuotas positivas, es decir, sin que ningún artículo prevea la posibilidad de utilizar otro método alternativo de cuantificación de las plusvalías, al mismo tiempo que no se contempla el supuesto de una minusvaloración en la enajenación de inmuebles, considerando siempre que existe un incremento por el que tributar (Antecedente de Hecho núm. 3).

Por su parte, el Abogado del Estado centra su defensa en que el art. 107 no sería inconstitucional en todo caso, sino solo en la medida en que no hubiese incremento de valor ni real ni cierto y ello quedase claramente demostrado; además, arguye que tras la reforma de citado artículo por medio de la Ley 51/2002, de 27 de diciembre, de Reforma de la Ley 39/1988, de 28 de diciembre, Reguladora de las Haciendas Locales, se suprimió la referencia que se hacía al término "real", por lo que siempre va a existir una renta potencial gravable (en palabras del Abogado del Estado) y el principio de capacidad económica quedaría a salvo. Para cimentar su tesis indica expresamente que "el fundamento del impuesto no es gravar el incremento "real" provocado por la diferencia de precios de venta y compra, sino la riqueza potencial, esto es, el incremento del valor del terreno experimentado por la acción urbanística del municipio en que se encuentra" (Antecedente de Hecho núm. 6) ${ }^{30}$. Asimismo, entiende que si el valor catastral se tiene en cuenta para la base imponible del tributo y dicho valor no se corresponde con el real, habrá que revisar dichas valoraciones, sin que ello afecte a la capacidad económica gravada.

En cuanto a los argumentos esgrimidos por el Fiscal General del Estado (Antecedente de Hecho núm. 7), entiende que la cuestión de inconstitucionalidad se debe ampliar

terrenos (plusvalias), Dykinson, Madrid, 2004, págs. 32 y ss.; CARBAJO VASCO, F.: "El gravamen de las plusvalías en España a la luz de las reformas en los países de la O.C.D.E.” en la Obra Colectiva: El impuesto sobre la renta de las personas físicas: pasado, presente y futuro del tributo, XXXVII Semana de Estudios de Derecho Financiero, Madrid, 1991, págs.. 379 y ss.; CAYÓN GALIARDO, A.: "Reflexiones sobre el Impuesto Municipal de Plusvalías y la reforma de las Haciendas Locales de 1975", Revista Española de Derecho Financiero, núm. 31, 1981, págs. 481 y ss.; D’CÓN, J.: "Algunas consideraciones en torno a la Ley de Haciendas Locales, con especial referencia al impuesto de plusvalía", Revista de Hacienda Local, núm. 87, 1999, págs. 569 y ss. y VÁZQUEZ VILLAMOR, J.A.: "La posible inconstitucionalidad del sistema de cálculo del Impuesto sobre el Incremento de Valor de los Terrenos de Naturaleza Urbana (plusvalía municipal)", Revista del Sector Inmobiliario, núm. 166, 2016, págs. 52 y ss.

30

El Abogado del Estado llega a sugerir incluso que se compense -figurativamente hablandolas plusvalías obtenidas en años anteriores con las bajadas de precios actuales, como puede leerse en el mismo Antecedente de Hecho núm. 6: "Es cierto, entonces (...) que los precios de los inmuebles han bajado respecto a años anteriores y en la que le titular de un inmueble puede verse obligado a enajenarlo por un precio inferior al de adquisición (...) puede ocurrir que, pese a haber obtenido una pérdida económica, a efectos del Impuesto municipal se aprecie un incremento del valor del terreno. Pero ello no es contrario al principio de capacidad económica (...). Durante las décadas anteriores y sobre todo en los años del llamado "boom inmobiliario", el valor de mercado de los inmuebles se incrementaba muy por encima de los valores catastrales, mientras que en el Impuesto municipal se tributaba igualmente en función del valor catastral y no del valor de mercado (...)". 
también al art. 110.4 de la misma Ley Reguladora de las Haciendas Locales, puesto que dicho precepto impide a los Ayuntamientos tener en cuenta los supuestos de decremento de valor de los inmuebles, pues no permite que puedan "atribuirse valores, bases o cuotas diferentes de las resultantes de tales normas".

Con todo lo anterior, el Alto Tribunal resuelve declarando la inconstitucionalidad de los arts. 107.2 y 110.4 de la norma citada y, para ello, se basa en los siguientes argumentos:

En primer lugar, considera que el gravamen no se anuda necesariamente a la existencia de un "incremento", sino a la mera titularidad del terreno durante un período de tiempo computable (entre uno y veinte años); por lo tanto, basta con ser titular de un terreno de naturaleza urbana para que se dé dicha circunstancia. Sin embargo, el nacimiento de la obligación tributaria se hace depender de la transmisión de un terreno, pero sin que sea, en modo alguno, una condición suficiente para ello en un tributo que quiere gravar el "incremento de valor". Por lo tanto, juzga el Tribunal Constitucional -con acierto a nuestro parecer- que a esa transmisión hay que añadir la necesaria materialización de una plusvalía en el mismo, exponente de la capacidad económica, si no real, al menos potencial. Con ello, se indica que si no se ha producido ese incremento la capacidad económica se convierte en irreal o ficticia violándose el art. 31.1 de la Constitución (Fundamento de Derecho Tercero).

En segundo término, el Tribunal incide en que los preceptos cuestionados otorgan a los supuestos de no incremento -incluso de decremento- un tratamiento de renta ficticia, igualando dichos supuestos a una plusvalía real, cuando no existe una auténtica capacidad o riqueza gravable.

En tercer lugar, no admite el razonamiento del Abogado del Estado en relación con la falta de actualización de los valores catastrales -tanto en épocas de bonanza económica como de crisis- puesto que, si dichos valores deben revisarse -al alza o a la baja- ello no obsta para que, utilizándolos, se intente gravar una riqueza inexistente, pues no ha habido incremento de valor alguno (Fundamento de Derecho Cuarto).

Concluye indicando que los dos artículos deben ser declarados inconstitucionales, aunque solo en la medida en que no han previsto excluir del tributo las situaciones inexpresivas de capacidad económica por inexistencia de incrementos de valor, con lo que viene a decir que una modificación legal en dicho sentido salvaría la constitucionalidad de los mismos, haciendo recaer la responsabilidad en el legislador para que modifique o adapte el régimen legal del impuesto para que no se someta a tributación los incrementos de valor inexistentes (Fundamento de Derecho Quinto).

A nuestro parecer, el Tribunal Constitucional dicta en esta ocasión una resolución acertada, pues era llamativa desde tiempo atrás, la vulneración al principio de capacidad económica por parte del Impuesto municipal de Incremento de Valor. Evidentemente no se trata de suprimir dicho gravamen -cuestión aparte es la sobreimposición a la que se someten las plusvalías inmobiliarias, lo que excede los límites de este estudio--, sino de poner de manifiesto que con la forma de calcular la base imponible, aplicando unos porcentajes sobre el valor catastral del terreno y no 
mediante la diferencia entre los valores de adquisición y transmisión del inmueble -como se hace en el Impuesto sobre la Renta de las Personas Físicas-, se estaba incidiendo sobre una riqueza irreal, es decir, sobre un supuesto en el que no existía tal riqueza.

En definitiva, es de esperar que ahora el legislador se plantee una reforma -a la que le empuja el Alto Tribunal- del citado Impuesto de plusvalías y declare la exención total de los casos en que se demuestre que el valor de los terrenos enajenados no ha experimentado un ascenso ${ }^{31}$. Con ello se respetaría plenamente la máxima a la que dedicamos este trabajo ${ }^{32}$.

\section{REFLEXIÓN FINAL: ¿ESTÁ SUPERADA DICHA MÁXIMA CONSTITUCIONAL?}

Una vez expuestos los problemas prácticos que hemos encontrado en la regulación de los tres impuestos estatales directos de más enjundia, tanto recaudatoria como de peso en el sistema tributario, así como del problema en el ámbito municipal de las plusvalías, no nos resta sino hacer una reflexión en voz alta acerca de si la mención de la capacidad económica en la Constitución Española de 1978 no es sino una declaración de intenciones que se está viendo sobrepasada por la forma real de legislar por parte del poder tributario.

Como hemos puesto de manifiesto, existen abundantes casos en los que no se tiene en cuenta dicha capacidad ni para medir la base imponible del gravamen, ni se emplea

31 Los problemas de los posibles efectos de la Sentencia del Tribunal Constitucional se ponen de manifiesto por TRIANA REYES, B.: "Efectos de las sentencias del TC tras la nueva Ley del Sector Público: al hilo de la reciente anulación parcial del impuesto de plusvalías que cobran los Ayuntamientos”, Diario La Ley, núm. 8961, 2017, pág. 3 y ss. Por su parte, MOLINS SANCHO, F. da noticia de la intención de la Federación Española de Municipios y Provincias de trasladar al Gobierno dos propuestas para la modificación del Impuesto sobre el Incremento del valor de los terrenos de naturaleza urbana. Según dicha Federación los recientes fallos jurisprudenciales del Tribunal Constitucional han creado una situación de inseguridad jurídica que debe ser suplida por el legislativo. Las propuestas que se plantean desde la FEMP pivotan bien en el catastro, mediante la aprobación de «índices objetivos» que determinen si ha habido incremento o no y susceptibles de ser actualizados en los presupuestos generales del Estado, bien en el precio reseñado en las escrituras públicas de compraventa. (Vid.: "La reforma del impuesto de plusvalía a debate", Diario La Ley, núm. 9030, 2017, págs. 12 y ss.). Véase también la opinión de DE UÑA REPETTO, J.: "El impuesto de "plusvalía municipal" en inmuebles transmitidos con pérdidas", Carta Tributaria, núm. 27, 2017 (revista de opinión).

32 Sin embargo, en la práctica hasta el momento en que se concluye la redacción de este trabajo (octubre de 2017) no se ha aprobado ninguna medida por el legislador estatal, lo que contribuye a las dudas y dificultades en la realidad recaudatoria de los municipios; en efecto, se han empezado a plantear las dudas acerca de las posibles devoluciones de las cuotas cobradas por el Impuesto en los casos en que no haya habido incremento real de valor, basándose en la declaración de inconstitucionalidad. Incluso se plantea el problema de extender la misma al plazo de prescripción tributaria, hecho que tiene cierta lógica, por lo que sería de agradecer una toma de postura del poder ejecutivo en este ámbito o, al menos, una Circular u Orden Interpretativa del Ministerio de Hacienda en este sentido. 
para modular la cuota tributaria a pagar, circunstancias que vimos en el epígrafe relativo a la conceptuación del principio que son consustanciales a su articulación práctica.

Todo ello lleva a pensar que se ha vaciado de contenido el artículo 31.1 de la Constitución, al menos en lo que en relación a este estudio hemos tratado y que prima en la voluntad del legislador una forma de estructurar algunos impuestos que se dirige fundamentalmente a asegurar unos ingresos tributarios. Para lograr esta finalidad se simplifica en ocasiones las mecánicas de integración de ingresos o las de gastos y beneficios fiscales, de manera que no se distinguen situaciones que son diversas desde el punto de vista de la riqueza del contribuyente. En otros supuestos, se distingue excesivamente entre tipos de renta que conduce a que se otorguen beneficios fiscales de los que se amparan sujetos pasivos con rentas más elevadas, lo que, nuevamente, conculca la máxima de la capacidad económica.

En definitiva, no podemos concluir este trabajo sin desear que las futuras modificaciones y reformas tributarias sean más cuidadosas en este extremo y que uno de los pilares del sistema fiscal español, al igual que otros países de nuestro entorno, se tenga en cuenta para ello, evitando así que, a la ya de por sí gravosa presencia de los impuestos, se añada la de una importante injusticia en su articulación y estructura.

\section{BIBLIOGRAFÍA}

AIZEGA ZUBILLAGA, J.M.: La utilización extrafiscal de los tributos y los principios de justicia tributaria, Universidad del País Vasco, Bilbao, 2001.

ALBIÑANA GARCÍA-QUINTANA, C.: “Artículo 31. El gasto público”, Comentarios a las Leyes Políticas, dirección ALZAGA, O., tomo III, Edersa, Madrid, 1983.

ALBIÑANA GARCÍA-QUINTANA, C.: "Génesis y trayectoria del Impuesto Municipal de Plusvalía", Revista de Estudios de la Administración Local y Autonómica, núm. 228, 1985.

ÁLVAREZ ARROYO, F.: Impuesto municipal sobre el incremento de valor de los terrenos (plusvalías), Dykinson, Madrid, 2004.

APARICIO PÉREZ, A.: "La falacia de la capacidad económica como criterio informador de los tributos", Información Fiscal, núm. 79, 2007.

CARBAJO VASCO, F.: “El gravamen de las plusvalías en España a la luz de las reformas en los países de la O.C.D.E." en la Obra Colectiva: El impuesto sobre la renta de las personas físicas: pasado, presente y futuro del tributo, XXXVII Semana de Estudios de Derecho Financiero, Madrid, 1991.

CAYÓN GALIARDO, A.: "Reflexiones sobre el Impuesto Municipal de Plusvalías y la reforma de las Haciendas Locales de 1975", Revista Española de Derecho Financiero, núm. 31, 1981.

CORCUERA TORRES, A.: “La exención de deportistas de alto nivel en la nueva Ley del Impuesto sobre la Rentas de las Personas Físicas", Revista Jurídica de Deporte y Entretenimiento, núm. 2, 1999. 
CORTÉS DOMÍNGUEZ, M.: "Los principios generales tributarios", XVI Semana de Estudios Financieros, Edersa, Madrid, 1968.

D'CóN, J.: “Algunas consideraciones en torno a la Ley de Haciendas Locales, con especial referencia al impuesto de plusvalía”, Revista de Hacienda Local, núm. 87, 1999.

DELGADO GARCÍA, A.M. y OLIVER CUELLO, R.: “Aspectos fiscales de la discapacidad y la dependencia", en la Obra Colectiva: Hacia una visión global de los mecanismos jurídico-privados de protección en materia de discapacidad, El Justicia de Aragón, Zaragoza, 2010.

DE UÑA REPETTO, J.: “El impuesto de "plusvalía municipal” en inmuebles transmitidos con pérdidas", Carta Tributaria, núm. 27, 2017.

ESCRIBANO LÓPEZ, F.: La configuración jurídica del deber de contribuir. Perfiles constitucionales, Civitas, Madrid, 1988.

FALSITTA, G. Manuale di Diritto Tributario. Parte Generale, $2^{\mathrm{a}}$ ed., Cedam, Padua, 1997.

FERNÁNDEZ JUNQUERA, M. y GARCÍA-OVIES SARANDESES, I.: "Una visión sobre la financiación autonómica", Nueva Fiscalidad, núm. 4, 2016.

GARCÍA NOVOA, C.: “La deducibilidad de las retribuciones a los administradores en el Impuesto de Sociedades", Quincena Fiscal, núm. 8, 2009.

GARCÍA NOVOA, C.: “Exenciones en el IRPF de las ayudas a deportistas de alto nivel y de las indemnizaciones por despido percibidas por técnicos y jugadores", en la Obra Colectiva: Régimen Tributario del Deporte, Thomson-Reuters, Navarra, 2013.

GONZÁLEZ GARCÍA, A.L.: “Las insolvencias en el Impuesto sobre Sociedades", Hacienda Pública Española, núm. 47, 1977.

GUERVÓS MAÍLLO, M.A.: “Medidas fiscales sobre la dependencia y la discapacidad en la Unión Europea y en España", Noticias de la Unión Europea, núm. 303, 2010.

HERRERA MOLINA, P.M.: Capacidad económica y sistema fiscal. Análisis del ordenamiento español a la luz del Derecho alemán, Marcial Pons, Madrid, 1998.

MAGRANER MORENO, F.J.: “Un “esperado" giro jurisprudencial en torno a la calificación de las retribuciones de los administradores como gasto en el Impuesto sobre Sociedades", Tribuna Fiscal, núm. 256, 2012.

MALVÁREZ PASCUAL, L.A.: "Régimen fiscal de la entrega a los trabajadores de acciones de la empresa", Revista de Contabilidad y Tributación, núm. 169, 1997.

MALVÁREZ PASCUAL, L.A. y MARTÍN ZAMORA, M.P.: “Las nuevas reducciones de la base imponible en el Impuesto sobre Sociedades: las reservas de capitalización y nivelación", Contabilidad y Tributación, núm. 383, 2015.

MARTÍNEZ AZUAR: "Rendimientos del capital inmobiliario e imputaciones de renta inmobiliarias tras la Ley 35/2006 del IRPF”, Técnica Tributaria, núm. 80, 2008.

MÍNGUEZ CONDE, J.L.: “La reserva de capitalización en la Ley 27/2014, de 27 de noviembre, del Impuesto sobre Sociedades”, Quincena Fiscal, núm. 13, 2015. 
MOLINS SANCHO, F.: “La reforma del impuesto de plusvalía a debate”, Diario La Ley, núm. 9030, 2017.

NIETO MONTERO, J.J.: "El principio de capacidad contributiva y su reflejo en la jurisprudencia constitucional", Revista de Derecho Financiero y de Hacienda Pública, núm. 238, 1995.

NIETO MONTERO, J.J.: “El artículo 31 de la Constitución Española: ¿otra víctima de la crisis económica?”, Dereito, vol. 22, noviembre, 2013.

RODRÍGUEZ BEREIJO, A.: “El deber de contribuir como deber constitucional. Su significado jurídico", Revista Española de Derecho Financiero, núm. 125, 2005.

RODRÍGUEZ BEREIJO, A.: “Una vuelta de tuerca al principio de capacidad económica”, Revista Española de Derecho Financiero, núm. 142, 2009.

RODRÍGUEZ RAMOS, M.: "El régimen fiscal de la dependencia”, Revista xuridica da Universidade de Santiago de Compostela, núm. 2, 2008.

ROMERO ABOLAFIO, J.J.: "Proyección de los valores superiores sobre la fiscalidad y el gasto público", Nueva Fiscalidad, núm. 3, 2016.

ROJí CHANDRO, L.A. y ROJí PÉREZ, S.: “Las empresas de reducida dimensión en el Impuesto sobre Sociedades: incentivos fiscales”, Revista Contable, núm. 52, 2017.

RUIZ GARIJO, M.: “¿Principio de capacidad económica en la cuantificación de la tasa por recogida de basuras? Una llamada sobre el carácter impositivo de algunas tasas", Jurisprudencia Tributaria, núm. 155, 2003.

RUIZ GARIJO, M.: Los rendimientos de capital inmobiliario en el nuevo IRPF, Edersa, Madrid, 2003.

SÁINZ DE BUJANDA, F.: Hacienda y Derecho. Estudios de Derecho Financiero, volumen III, Instituto de Estudios Políticos, Madrid, 1963.

TRIANA REYES, B.: "Efectos de las sentencias del TC tras la nueva Ley del Sector Público: al hilo de la reciente anulación parcial del impuesto de plusvalías que cobran los Ayuntamientos", Diario La Ley, núm. 8961, 2017.

VAQUERA GARCÍA, A.: "La tributación con fines ecológicos: El reciente gravamen francés para la protección del ambiente atmosférico", Revista de Información Fiscal, núm. 14, 1996.

VAQUERA GARCÍA, A.: Fiscalidad y Medio Ambiente, Lex Nova, Valladolid, 1999.

VAQUERA GARCÍA, A.: "Propuestas comunitarias sobre la fiscalidad de la energía", Noticias de la Unión Europea, núm. 193, 2000.

VAQUERA GARCÍA, A.: “La fiscalidad ambiental: algunas reflexiones actuales”, Nueva Fiscalidad, núm. 3, 2006.

VAQUERA GARCÍA, A.: “La tributación medioambiental en las Comunidades Autónomas y en el Derecho Comparado", Economía y medio ambiente, núm. 113, 2007.

VAQUERA GARCÍA, A.: “La protección ambiental como alternativa de financiación de las Comunidades Autónomas, el caso de los impuestos sobre usos y aprovechamientos 
del agua embalsada de Galicia y Castilla y León", Thomson Reuters-Lex Nova, Valladolid, 2013.

VARONA ALABERN, J.E.: "Concepto de tributo y principio de capacidad económica", Revista Española de Derecho Financiero, núm. 135, 2007.

VÁZQUEZ VILLAMOR, J.A.: “La posible inconstitucionalidad del sistema de cálculo del Impuesto sobre el Incremento de Valor de los Terrenos de Naturaleza Urbana (plusvalía municipal)", Revista del Sector Inmobiliario, núm. 166, 2016. 